\title{
Whiteschist genesis through metasomatism and metamorphism in the Monte Rosa nappe (Western Alps)
}

\author{
Cindy Luisier ${ }^{1,2}\left[\right.$ [ Lukas P. Baumgartner ${ }^{1} \cdot$ Benita Putlitz $^{1} \cdot$ Torsten Vennemann $^{3}$
}

Received: 30 March 2020 / Accepted: 12 November 2020 / Published online: 10 January 2021

(c) The Author(s) 2021

\begin{abstract}
Whiteschists from the Monte Rosa Nappe were examined in the field as well as with petrographic, geochemical, and isotopic methods to constrain the controversial origin of these rocks in their Alpine metamorphic context. Whiteschists occur as ellipsoidal-shaped, decametric-sized bodies, within a Permian metagranite, and consist mainly of chloritoid, talc, phengite, and quartz. The transition from whiteschist to metagranite is marked by multiple sharp mineralogical boundaries defining concentric zones unrelated to Alpine deformation. The development of reaction zones, as well as the geometry of the whiteschist suggest a pervasive fluid infiltration, facilitated and canalized by reaction fingering. Whole-rock compositions of whiteschists and metagranites indicate an enrichment in $\mathrm{MgO}$ and $\mathrm{H}_{2} \mathrm{O}$ and depletion of $\mathrm{Na}_{2} \mathrm{O}, \mathrm{CaO}, \mathrm{Ba}, \mathrm{Sr}, \mathrm{Pb}$, and $\mathrm{Zn}$ in the whiteschist relative to the metagranite. Trace- and rare-earth elements, together with all other major elements, notably $\mathrm{K}_{2} \mathrm{O}$ and $\mathrm{SiO}_{2}$, were within uncertainty not mobile. Such a $\mathrm{K}$ and $\mathrm{Si}$ saturated, Na undersaturated fluid is not compatible with previous interpretations of fluids derived from ultramafic rocks, evaporites, or Mg-enriched seawater due to mantle interactions. Together with the large variations in $\delta \mathrm{D}$ and $\delta^{18} \mathrm{O}$ values, this indicates large fluid fluxes during metasomatism. Calculated $\delta \mathrm{D}$ and $\delta^{18} \mathrm{O}$ values of fluids in equilibrium with the whiteschist support a magmatic-hydrothermal fluid source, as does the chemical alteration pattern. Bulk rock ${ }^{87} \mathrm{Sr} /{ }^{86} \mathrm{Sr}$ ratios in whiteschists confirm a pre-Alpine age of fluid infiltration. The ${ }^{87} \mathrm{Sr} /{ }^{86} \mathrm{Sr}$ ratios in whiteschists were subsequently partially homogenized in a closed system during Alpine metamorphism. In conclusion, the granite was locally affected by late magmatic-hydrothermal alteration, which resulted in sericite-chlorite alteration zones in the granite. The entire nappe underwent high-pressure metamorphism during the Alpine orogeny and the mineralogy of the whiteschist was produced during dehydration of the metasomatic assemblage under otherwise closed-system metamorphism. While each whiteschist locality needs to be studied in detail, this in-depth study suggests that many whiteschists found in granitic bodies in the Alps might be of similar origin.
\end{abstract}

Keywords Whiteschist $\cdot$ Metasomatism $\cdot$ Hydrothermal alteration $\cdot$ High-pressure metamorphism

\section{Introduction}

Communicated by Steven Reddy.

Supplementary Information The online version of this article (https://doi.org/10.1007/s00410-020-01759-0) contains supplementary material, which is available to authorized users.

Cindy Luisier

cindy.luisier@gmail.com

1 Institute of Earth Sciences, University of Lausanne, Lausanne, Switzerland

2 University of Rennes, CNRS, Géosciences Rennes, UMR 6118, Rennes, France

3 Institute of Earth Surface Dynamics, University of Lausanne, Lausanne, Switzerland
Whiteschists have first been described as talc and kyanite schists by Schreyer (1973) after the discovery of a number of occurrences of this special magnesium-aluminium-rich paragenesis in various geological settings over the world (Schreyer 1974). They are commonly found in continental units that underwent medium-to-high-pressure metamorphism and, depending on the metamorphic grade, various Mg-Al silicates are reported (Schreyer and Seifert 1969). The chemical composition of the rocks is relatively simple (Franz et al. 2013): $\mathrm{K}_{2} \mathrm{O}-\mathrm{FeO}-\mathrm{MgO}-\mathrm{Al}_{2} \mathrm{O}_{3}-\mathrm{SiO}_{2}-\mathrm{H}_{2} \mathrm{O}$ (KFMASH). The rarity of these rocks and their simple composition has attracted the curiosity of petrologists, since there is no common protolith for this unusual rock. 
Numerous protoliths have been proposed, but these are still debated.

In the Western Alps, whiteschists are found in the three Internal Crystalline Massifs: Monte Rosa, Gran Paradiso, and Dora Maira. Bearth (1952) and later Dal Piaz and Lombardo (1986) interpreted the whiteschists from the Monte Rosa as products of a metasomatic alteration of granites based on field evidence. Alternatively, a protolith consisting of meta-evaporites or Mg-rich pelites has been proposed by Chopin (1981) and Schreyer (1977). These two propositions have since been supplemented to include rocks of metasedimentary or metavolcanic origin in crustal domains (Chopin 1984; Schertl et al. 1991). The discrete and isolated character of the whiteschist occurrences within the Dora Maira orthogneisses later led Chopin et al. (1991) to favor Bearth's (1952) original interpretation though. The metasomatic origin of the Dora Maira whiteschist protolith was also supported by subsequent workers (Schertl et al. 1991; Gebauer et al. 1997; Compagnoni and Hirajima 2001). A metasomatized granite origin of the whiteschists in the Monte Rosa nappe was argued for by Pawlig and Baumgartner (2001).

The timing of alteration, as well as the source of the fluids is also a matter of debate. Ferrando (2012) argued that the whiteschists found in the Internal Crystalline Massifs of the Western Alps have many characteristics in common and, hence, have a common origin. Ferrando (2012) proposed that they are the result of $\mathrm{Mg}$ metasomatism, related to dehydration of ultramafic rocks, which interacted with ocean water. Based on geochemical and fluid-inclusion studies, she proposed that fluid-rock interaction is localized along highstrain zones. Different tectonic environments were suggested for the metasomatic event, including continental-oceanic transition zones, subduction, and continent-continent collision zones. Based on a stable isotope study, Sharp et al. (1993) proposed a metasomatic fluid originating from the dehydration of altered oceanic crust at great depth for the Dora Maira slice during the Alpine orogeny. In contrast, Pawlig and Baumgartner (2001) used stable isotope and whole-rock compositions to suggest that the alteration is the result of late-stage magmatic-hydrothermal fluid-rock interaction, which occurred during the Permian, thus prior to Alpine metamorphism. In a recent study, Chen et al. (2019) suggest that the metasomatic fluids of the Dora Maira whiteschist were reduced fluids, emphasizing the role of oxygen fugacity on the formation of whiteschist.

The present study contributes to the debate on the origin of whiteschists by presenting detailed field and geochemical data to clarify the nature and timing of the metasomatic alteration. The southwestern edge of the Monte Rosa nappe has been the focus of studies on whiteschists since Bearth's seminal work (Bearth 1952; Chopin and Monié 1984; Pawlig and Baumgartner 2001; Darbellay 2005). More recently, the whiteschists have been at the centre of highly controversial idea of tectonic over-pressure (Luisier et al. 2019). A crucial part not addressed in the above-mentioned short paper is the origin of the chemical composition of the whiteschist, discussed in detail here. In the Val d'Ayas area, two whiteschists occur as 10-50 m large bodies within the Monte Rosa metagranite, and two others are located at the contact between the metagranite and the surrounding basement paragneisses. The two whiteschists occurring within the metagranite have been less affected by the late Alpine, retrograde overprint and maintained their Alpine peak metamorphic paragenesis of talc-chloritoid-phengite-quartz. Field and petrographic observations are complemented by an extensive whole rock and stable isotope geochemical study, to help identify the fluid source responsible for the metasomatic alteration leading to the whiteschist formation. Finally, rubidium-strontium whole-rock data will complement the field study to establish the timing of the fluid event.

\section{Geological setting}

The Monte Rosa nappe is a basement nappe belonging to the middle Penninic unit of the Western Alps (Bearth 1952). It forms a large backfold, structurally enclosed by the ultramafic and mafic rocks of the Zermatt-Saas unit above and the Antrona unit below (Steck et al. 2015). From a paleogeographic point of view, the Monte Rosa nappe represents the southernmost tip of the Briançonnais microcontinent that belongs to the European continental margin (Dal Piaz 2001; Steck et al. 2015).

The nappe consists of pre-Alpine polymetamorphic paragneisses (Fig. 1), locally containing small volumes of amphibolite boudins and carbonate layers (Bearth 1952; Dal Piaz 1971), which underwent high-grade amphibolite facies regional metamorphism during the Variscan orogeny at conditions of $0.5-0.7 \mathrm{GPa}$ and temperatures in excess of 650 ${ }^{\circ} \mathrm{C}$, locally resulting in the partial melting of the basement rocks (Bearth 1952; Dal Piaz 1971; Ferrando et al. 2002). The basement was intruded by Permian granites, dated at $269 \pm 4$ Ma by SHRIMP U-Pb on zircon (Pawlig 2001). Chopin and Monié (1984) were the first to investigate the Alpine peak metamorphism of the Monte Rosa nappe using a whiteschist sample from the Upper Ayas valley (Chopin and Schreyer 1983; Chopin and Monié 1984). They suggested temperatures of $500{ }^{\circ} \mathrm{C}$ and pressures of $1.6 \mathrm{GPa}$. Later, Le Bayon et al. (2006) obtained peak conditions of 2.4 $\mathrm{GPa}$ at $500{ }^{\circ} \mathrm{C}$. Luisier et al. (2019) present phase petrology arguments to suggest that the peak temperature and pressure in the whiteschists were $540-600{ }^{\circ} \mathrm{C}$ and $2.2 \mathrm{GPa}$, due to potential deviation from the lithostatic pressure, in a metagranite which records maximum pressures of $1.4 \mathrm{GPa}$. The age of the Alpine peak metamorphism was constrained by $\mathrm{U}-\mathrm{Pb}$ on rutile at $42.6 \pm 0.6 \mathrm{Ma}$ (Lapen et al. 2007) and followed by a greenschist-facies retrogression dated at 41.0 to 


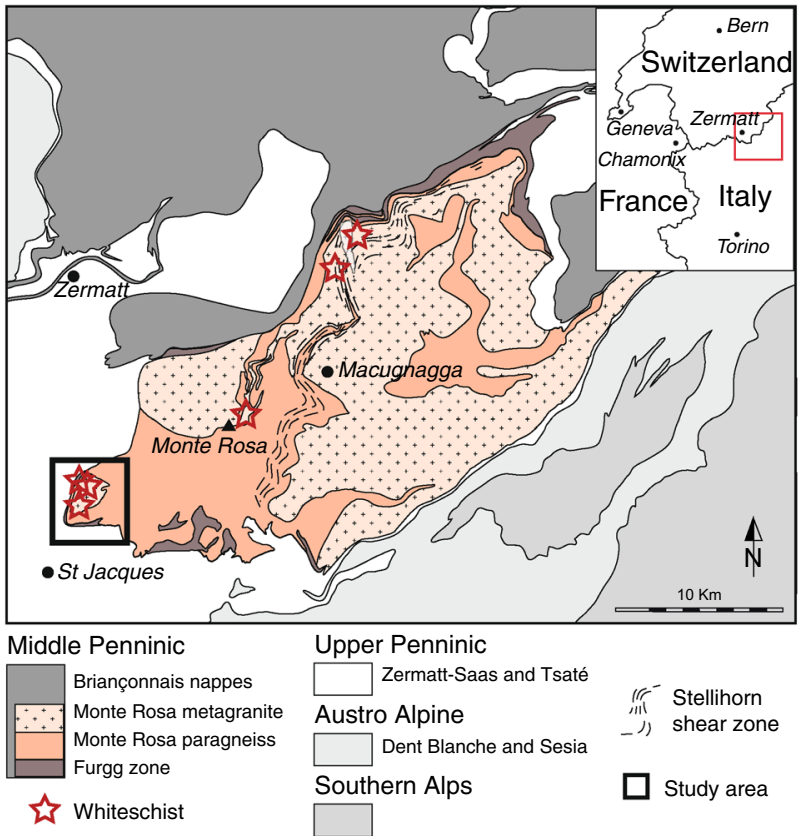

Fig. 1 Simplified tectonic and geological map of the Monte Rosa nappe (modified after Steck et al. 2015). The study area is outlined by the rectangle and whiteschist outcrops are marked by stars

38.5 Ma by $\mathrm{Rb}-\mathrm{Sr}$ on metasediments from the Schistes Lustrés (Skora et al. 2015). Fission track zircon and apatite data from the metagranite around the whiteschists are $34 \mathrm{Ma}$ and $14 \mathrm{Ma}$, respectively (Hurford et al. 1991), suggesting that this part of the Penninic domain was quickly exhumed after its peak metamorphism. The exhumation of the Monte Rosa nappe through extrusion and backfolding is related to major deformation structures that heterogeneously overprinted both the Alpine peak metamorphism in the metagranite and the polymetamorphic history of the paragneiss basement (Steck et al. 2015).

\section{Analytical methods}

Fresh samples were crushed using a hydraulic press and powdered in a tungsten carbide mill. Powders were first dried in the oven at $110^{\circ} \mathrm{C}$ and calcined at $1050{ }^{\circ} \mathrm{C}$ for $3 \mathrm{~h}$. LOI was calculated by weight difference before and after calcination. Calcined powders were mixed with $\mathrm{Li}_{2} \mathrm{~B}_{4} \mathrm{O}_{7}$ and melted to produce fused glass disks. Major elements were determined by X-ray fluorescence (XRF), using a PANalytical Axios-mAX spectrometer at the University of Lausanne, Switzerland. Ferrous iron was determined by a colorimetric method with a PerkinElmer Lambda 25 spectrophotometer at the University of Lausanne.

Glass disks were used for trace-element determination by LA-ICP-MS. A NewWave UP-193 ArF ablation system, combined with an Element XR at the University of Lausanne was employed. NIST SRM 612, was used as standard and $\mathrm{Al}_{2} \mathrm{O}_{3} \mathrm{XRF}$ compositions served as an internal standard.

The oxygen isotope composition of whole rocks was determined at the University of Lausanne using a $\mathrm{CO}_{2}$ laser fluorination technique with $\mathrm{F}_{2}$ as reagent (Lacroix and Vennemann 2015) coupled to a Thermo Finnigan MAT 253 gas source mass spectrometer. Whole-rock data are corrected to the session value of an in-house quartz standard, i.e., LS-1 Qtz with an accepted value of $18.1 \%$ o. The repeatability of the LS-1 determined as average of daily replicates is usually better than $0.2 \%$ ( $1 \mathrm{~s})$. Data are given in conventional $\delta$-notation, relative to Vienna Standard Mean Ocean Water (VSMOW).

Measurements of the hydrogen isotope compositions of minerals were made using high-temperature $\left(1450{ }^{\circ} \mathrm{C}\right)$ reduction methods with He-carrier gas and a TC-EA linked to a Delta Plus XL mass spectrometer from Thermo-Finnigan on 2-4 mg-sized samples according to a method adapted after Bauer and Vennemann (2014). The precision of the in-house kaolinite and G1 biotite standards for hydrogen isotope analyses was better than $\pm 2 \%$ for the method used; all values were normalized using a value of $-125 \%$ o for the kaolinite standard and $-65 \%$ o for NBS-30. The data are given in the standard $\delta$-notation, expressed relative to VSMOW in permil (\%o).

Six samples from the Mezzalama whiteschist containing carbonates have been selected for measurements of the $\delta^{13} \mathrm{C}$ and $\delta^{18} \mathrm{O}$ values. All samples come from Zone $\mathrm{C}$ of the transition zone described below. One is a carbonate vein (14MR12) and the five other samples contain carbonate as a matrix phase. The carbonate powder from sample 14MR12 was obtained by micro-drilling and bulk rock powders were used for the other five samples. The $\mathrm{C}$ - and $\mathrm{O}$-isotope composition of the carbonates were measured with a GasBench II connected to a Finnigan MAT DeltaPlus XL mass spectrometer, according to a method adapted after Spötl and Vennemann (2003). In-house standards of calcite are treated in the same way and run interspersed with the samples in the same sequence. Samples are normalized using an inhouse standard calibrated against $\delta^{13} \mathrm{C}$ and $\delta^{18} \mathrm{O}$ values of NBS-19 (+1.95 and $-2.20 \%$, relative to VPDB). External reproducibility for the analyses estimated from replicate analyses of the in-house standard reacted at $70{ }^{\circ} \mathrm{C}(n=5)$ was $\pm 0.04 \%$ ofor $\delta^{13} \mathrm{C}$ (expressed vs VPDB) and $\pm 0.06 \%$ o for $\delta^{18} \mathrm{O}$ (expressed vs VSMOW).

${ }^{87} \mathrm{Sr} /{ }^{86} \mathrm{Sr}$ ratios on bulk rock powders were measured at the Department of Mineralogy of the University of Geneva, Switzerland, after the method described in detail in Béguelin et al. (2015), using a Thermo Neptune PLUS multicollector ICP-MS. ${ }^{87} \mathrm{Sr} /{ }^{86} \mathrm{Sr}, \mathrm{Rb}$ and $\mathrm{Sr}$ contents have been used to calculate ${ }^{87} \mathrm{Rb} /{ }^{86} \mathrm{Sr}$ ratios, using the abundance of ${ }^{87} \mathrm{Rb}$ as 0.278346 of the atomic fraction, its mass of $85.46776 \mathrm{~g} / \mathrm{mol}$, 
the mass of $\mathrm{Sr}$ as $87,6148999 \mathrm{~g} / \mathrm{mol}$, and a ${ }^{86} \mathrm{Sr} /{ }^{88} \mathrm{Sr}$ ratio of 0.1194 and the ${ }^{84} \mathrm{Sr} /{ }^{88} \mathrm{Sr}$ ratio of 0.006756 . Strontium evolution diagram was calculated using lambda of $1.404 \times 10^{-11}$.

\section{Field observations and petrography}

The study area is located in the Upper Ayas Valley, in the Italian Alps (Fig. 1). Here, the hinge of the Monte Rosa backfold crops out and is surrounded by the two flanks of the overlying Zermatt-Saas serpentinite and metabasic rocks. The western extent of the basement paragneiss is restricted and affected by the late deformation related to greenschistfacies metamorphism (Darbellay 2005; Steck et al. 2015) and the proximity to the thrust contacts between the Monte Rosa nappe and the Zermatt-Saas unit. The paragneiss in the NW of the Mezzalama refuge has a variably strong foliation related to the Alpine deformation, overprinting the preAlpine metamorphic schistosity. The intensity of the Alpine deformation is decreasing from the thrust contact in the NW towards the SE, over a distance of a few tens of meters. The granite intrusive contact on the NW of the Mezzalama refuge is affected by the deformation as well, as shown by aplite and pegmatite dykes in the paragneiss that are bent into the Alpine foliation. On the other side, the SE intrusive contact (visible along the Perazzispétz ridge) is well preserved and relatively undeformed. A more-detailed structural study can be found in Darbellay (2005) and Vaughan-Hammon et al. (in review). The metagranite has large regions of undeformed to slightly foliated metagranite, separated by high strain, anastomosing ductile shear zones. The undeformed metagranite is a K-feldspar porphyritic biotite metagranite, locally containing granodiorite enclaves or paragneiss xenoliths. Alignment of the K-feldspars is visible in the least deformed parts and is interpreted to be of magmatic origin. The three whiteschist outcrops are described in detail in the following sections and identified by arrows in Fig. 2.

\section{Mezzalama whiteschist}

The best-preserved whiteschist is the Mezzalama whiteschist, located to the $\mathrm{N}$ of the Mezzalama refuge (624991/084967). It has not been described in detail previously, but is the location of the study of Luisier et al. (2019) on pressure variations. It crops out as an ellipsoidal-shaped body of $40 \times 20 \mathrm{~m}$, elongated in the SW-NE direction. In this area, the whiteschist-to-metagranite transition occurs over approximately $2-6 \mathrm{~m}$ and we define this zone as transition zone in this study.

The deformation in this area is given by a weak, NW dipping schistosity (Darbellay 2005), which is consistent with the main foliation in the area. The foliation is related to the nappe exhumation and back-folding (Steck et al. 2015), associated with a greenschist-facies metamorphic overprint.
The foliation is weak in the porphyritic metagranite at the contact with the whiteschist as well as in the transition zone between the whiteschist and metagranite. The centre of the whiteschist remained largely unaffected by any deformation. The orientation of the whiteschist-to-metagranite transition zone is almost vertical on the NW and NE sides of the whiteschist. It dips steeply towards SW on the SW side and dips towards the SE on the SE side of the whiteschist. The $\mathrm{NW}$-oriented foliation overprints and crosscuts the whiteschist-metagranite transition. This deformation event is younger than the metasomatic alteration and the whiteschist crystallisation. There is no shear zone or fault associated with this body (Fig. 3a, b). Moreover, straight pegmatite and aplite dykes crosscut the metagranite-whiteschist transition, without being deformed. Therefore, the whiteschist is a body, which is formed in-situ, surrounded by metasomatic alteration zones; it is not a xenolith, nor a tectonic slice or body mixed into the metagranite by any Alpine structural feature.

The transition between the whiteschist and the metagranite is characterized by two reaction fronts, delimited by sharp mineral boundaries. K-feldspar (Kfs) disappears abruptly in the transition zone (Fig. 4a, b), while round, globular igneous quartz continuous straight into the whiteschist. This allows to visually track the geometry of the whiteschist-metagranite transition and confirms that the protolith of the whiteschist was indeed the Monte Rosa granite. The metasomatic zones can be straight (Fig. 4a) or lobate (Fig. 4b). The pegmatite and aplite dykes, which crosscut the metagranite-whiteschist boundary, are also turned into whiteschist (Fig. 4a), preserving their outlines in places due to their initially different grain size (Fig. 3b). These field observations are important evidence that excludes a xenolith origin of the whiteschist and confirm the previous interpretations that the metagranite is the protolith of the whiteschist (Pawlig and Baumgartner 2001; Marger et al. 2019).

The central, inner part of the whiteschist outcrop (hereafter referred to as zone $\mathrm{A}_{\text {in }}$ ) consists of an assemblage of chloritoid, phengite, talc, and quartz, defining the peak Alpine paragenesis. Fine-grained kyanite, sericitic phengite, and chlorite are present as retrograde products in minor amounts ( $<5 \mathrm{vol} \%)$, replacing chloritoid. Accessory minerals include zircon, tourmaline, monazite, florencite, allanite, apatite, rutile, pyrite, and iron oxide. The outer part of the whiteschist is labelled hereafter Zone $\mathrm{A}_{\text {out }}$. It becomes successively more retrogressed towards Zone B. Here, chlorite and white mica pseudomorphose chloritoid (Fig. 5b), chlorite flakes pseudomorphose talc, and fine-grained white mica and chlorite are found in the matrix, together with quartz. The subdivision of the Zone A into two subzones (inner, outer) is done to separate the well-preserved high-pressure paragenesis in the centre of the whiteschist outcrop from the greenschist-facies retrogressed rim of the 


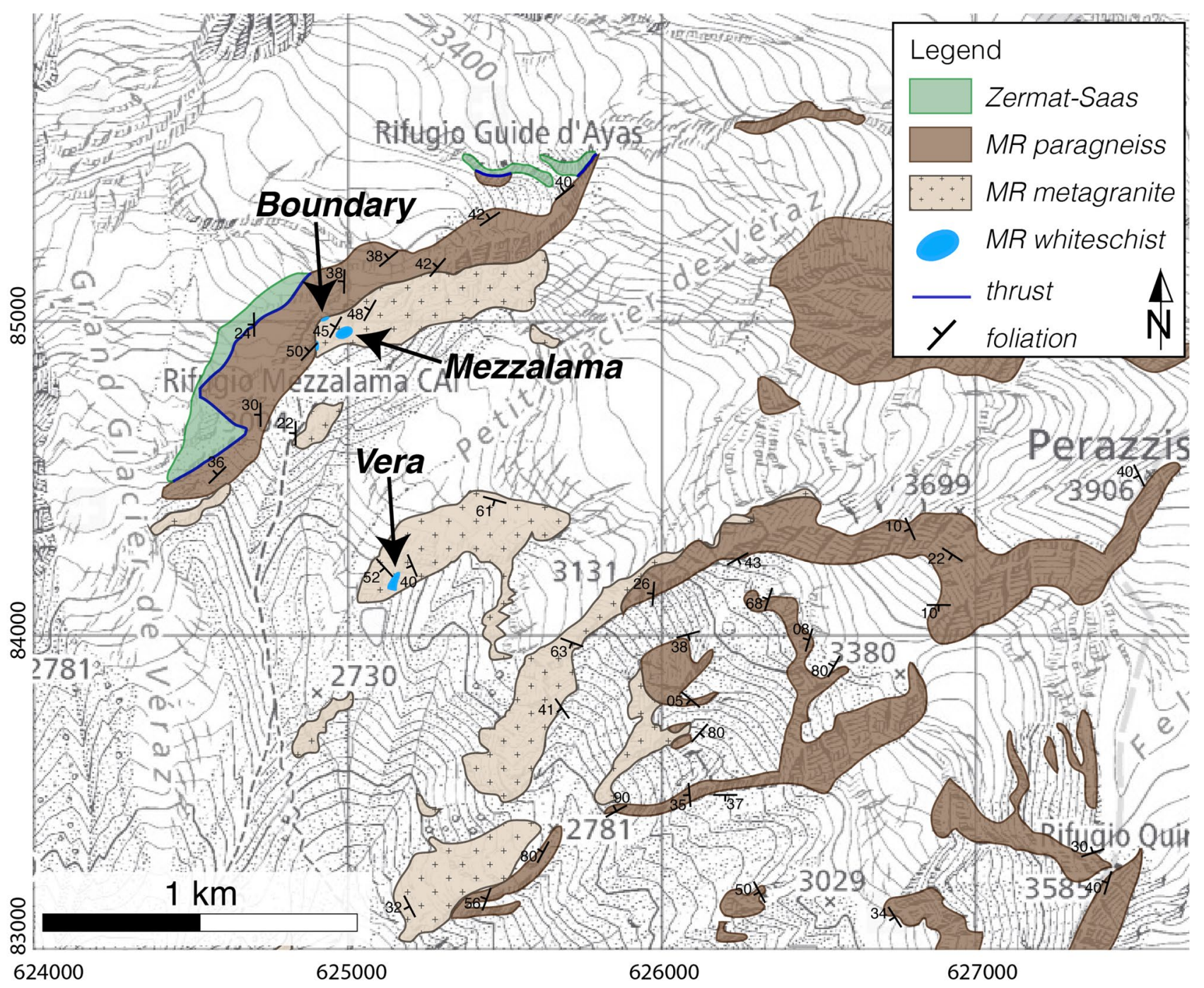

Fig. 2 Geological map of the study area, displaying the main lithologies. MR = Monte Rosa. Simplified and adapted after Darbellay (2005). The three whiteschist outcrops (Mezzalama, Vera and Boundary) are labeled by arrows

whiteschist outcrop. The transition between the whiteschist in Zone A and Zone B is marked by the complete disappearance of chloritoid-even pseudomorph outlines are no longer visible - and the appearance of plagioclase neoblasts, leading to an assemblage of chlorite, phengite, quartz, and plagioclase (Fig. 5c). Zone $\mathrm{C}$ marks the disappearance of chlorite and appearance of calcite. Calcite is present in the matrix, or as distinct aggregates of crystals (Fig. 5d, e) or in veins. The mineral assemblage characteristic of Zone $\mathrm{C}$ is phengite, quartz, plagioclase, and calcite, with locally small amounts of biotite and garnet. K-feldspar appears a few tens of centimetres to few metres further away, in the porphyritic metagranite. The porphyritic metagranite preserved its igneous mineralogy of K-feldspar, plagioclase, biotite, and quartz (Fig. 5f). Metamorphic minerals are phengite, small garnets, and a fine-grained assemblage of zoisite/ clinozoisite, albite with white mica pseudomorphically replacing igneous-textured plagioclase (Luisier et al. 2019).

A second small ellipsoidal body of around 1 square meter in size is found next to the main whiteschist described above and shares the same characteristics, except the absence of Zone $\mathrm{C}$.

Overall, from structural and petrographic observations on the Mezzalama whiteschist, the whiteschist body is interpreted to have a tube-like geometry (Fig. 3d). Mineralogical zonation as described above at the whiteschist-to-metagranite transition is typical for a metasomatic alteration front (e.g., Korzhinskii 1968; Dipple et al. 1998).

The fact that the inner part of the whiteschist remained undeformed during Alpine metamorphism suggests that the crystallization of the peak pressure mineral assemblage in the whiteschist occurred under static conditions. The 


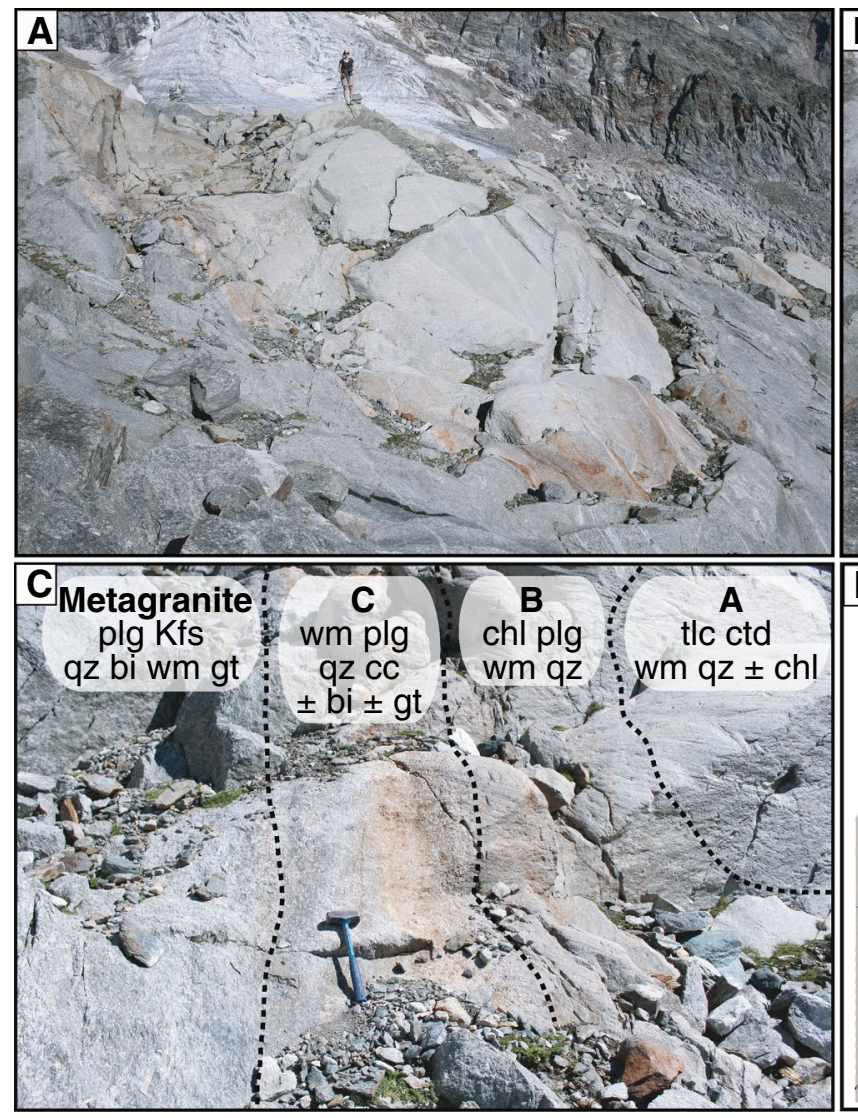

Fig. 3 a Picture of the Mezzalama whiteschist outcrop. The view is towards the East. For scale note the person standing on top of the whiteschist outcrop b The transition zone and the proper whiteschist body are indicated by the line drawing superimposed on the previous image (a). Pegmatite and aplite dykes (dashed lines) crosscutt the metagranite/whiteschist boundary. Inside zone A they are transformed into whiteschist. Their outline is indicated by a change in grain size and abundance of trace minerals such as tourmaline. A red square delineates the location of Fig. 3c. c Detailed view of the transition zone between the whiteschist (zone A) and a porphyritic metagranite. The picture is oriented NW - SE and corresponds to the red square in (b). Zone A consists of whiteschist, zone B is marked by the appearance of plagioclase and disappearance of talc and chloritoid or their pseudomorphs, zone $\mathrm{C}$ is marked by the appearance of calcite, \pm bio-

observation that the whiteschist is not related to any shear zone or fault, combined with the fact that the protolith of the whiteschist was not deformed before high-pressure metamorphism, suggests that the initial shape of the whiteschist protolith was not a planar structure, but rather a tube-like structure in 3D.

\section{Boundary whiteschist}

The second whiteschist occurrence is located at the boundary between the metagranite and the surrounding

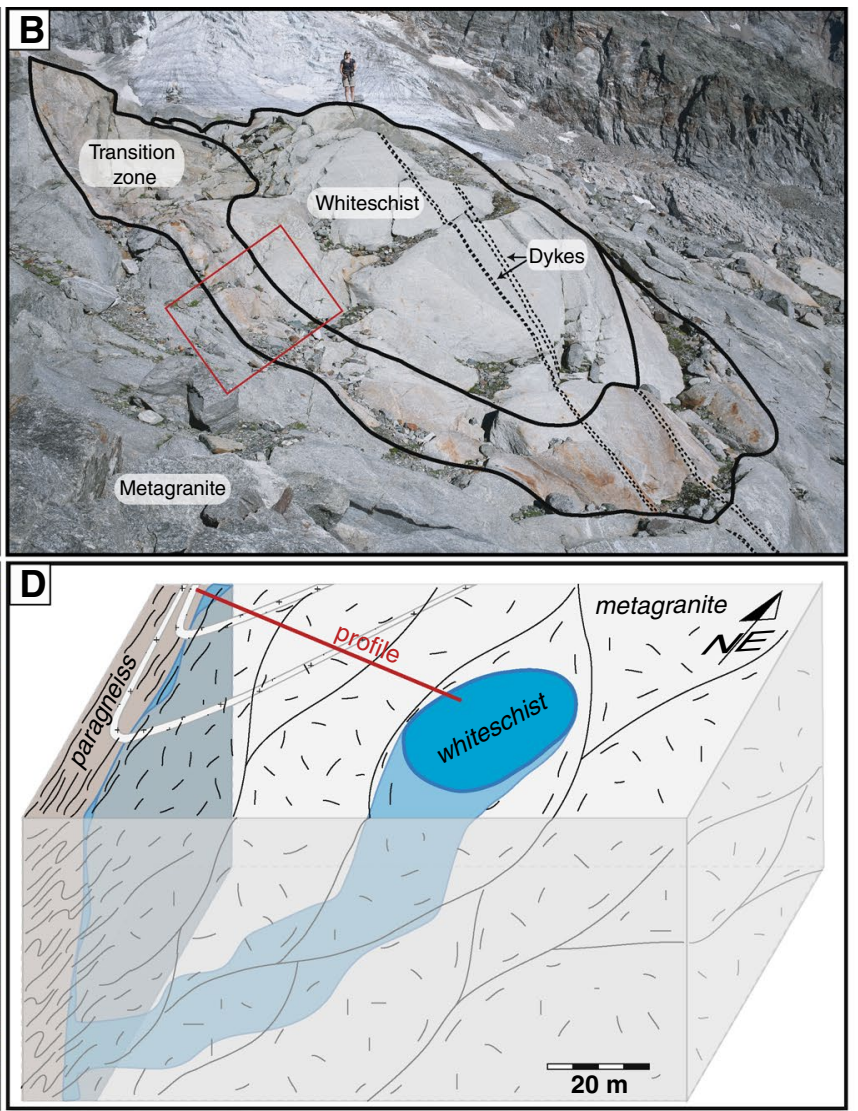

tite and garnet, and the disappearance of chlorite. The boundary to the porphyritic metagranite is marked by the disappearance of calcite, and the appearance of K-feldspar. The width of the transition zone is variable (0 to 6 meters). Details of the mineralogy can be found in Table 1. d 3D sketch illustrating the interpretation of the field geometry of the Mezzalama area. The outcropping shape is a $2 \mathrm{D}$ ellipsoid elongated in the NE - SW direction. Note that no shear zones are associated with the whiteschist. The steep boundaries around the outcrop implying a tube-like shape. The red line shows the the location of the samples profile discussed in Fig. 8a). The drawn lines illustrate the gradient in deformation intensity, decreasing from the NW to SE. Mineral abbreviations are: bi: biotite, cc: calcite, chl: chlorite, ctd: chloritoid, gt: garnet, Kfs: K-feldspar, plg: plagioclase, qz: quartz, tlc: talc, wm: white mica

polymetamorphic paragneiss on the NW of the Mezzalama refuge (624934/085013), just a few hundred meters northwest of the main Mezzalama whiteschist. Due to intense deformation, the whiteschist shows a strongly recrystallized and foliated greenschist facies mineralogy in most places. The assemblage of chlorite, white mica, and quartz and the presence of relict chloritoid are similar to the $A_{\text {out }}$ of the Mezzalama whiteschists. Accelerated snow melting has revealed a further undeformed whiteschist just to the South of this location, along the contact, which due to its recent discovery, could not be studied here. 
Fig. 4 a Picture of the contact between zone $\mathrm{C}$ (top) and metagranite (bottom). The sharp boundary is marked by the disappearance of milky-white igneous $\mathrm{K}$-feldspar (Kfs) grains form the granite protolith. Two dykes crosscutting the granite have also been turned into whiteschist. b Picture of a lobate transition between the granite and the whiteschist. Note the sharpness of the contact. Some larger quartz globules found in the granite can be traced into the whiteschist at this location

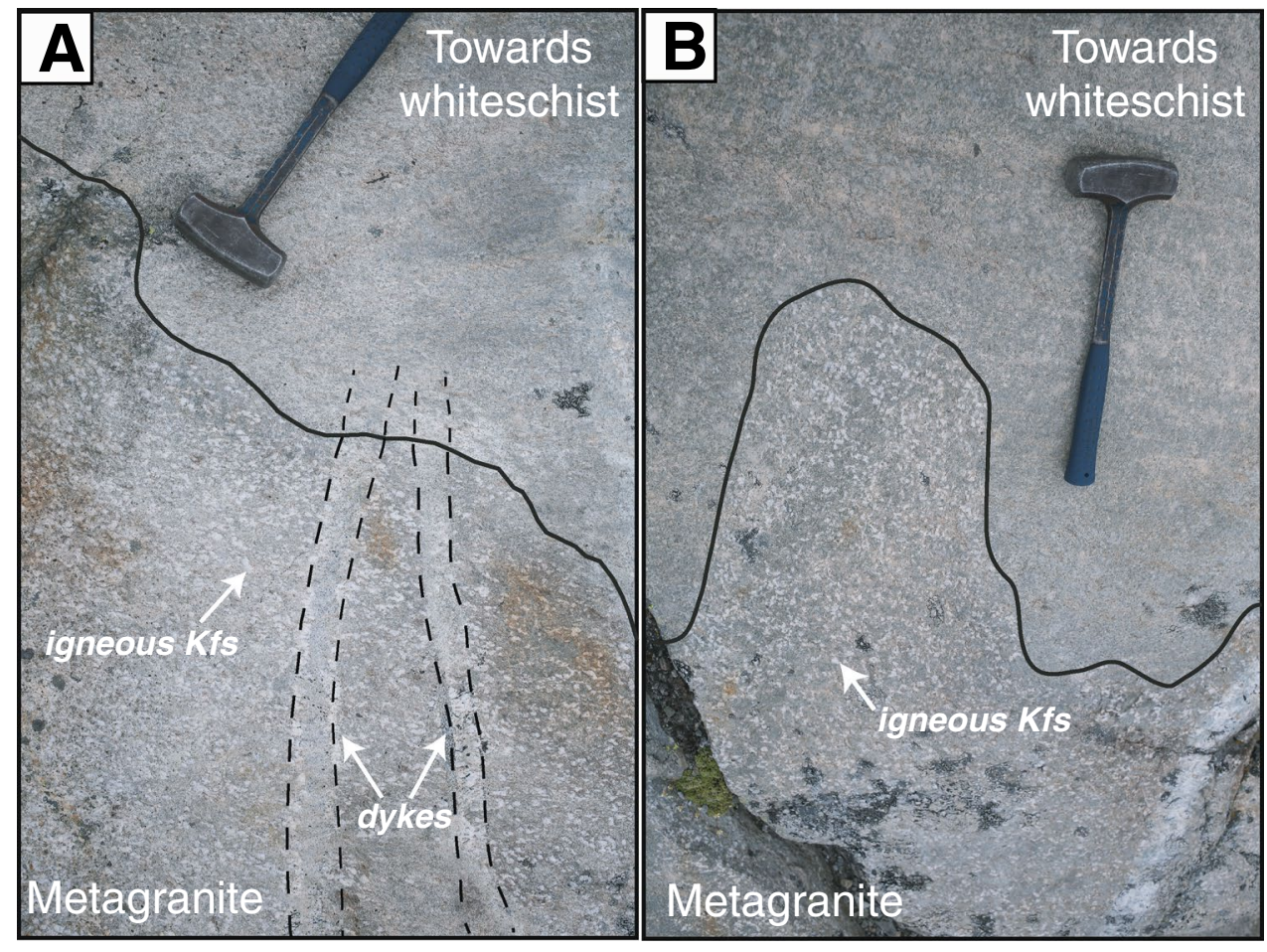

\section{Vera whiteschist}

The third whiteschist outcrop is located to the SE of the Mezzalama refuge, on the left bank of the Piccolo Ghiacciaro di Vera, above a small lake (625150/ 084184). It was first described by Dal Piaz (1971) and studied in detail by Pawlig and Baumgartner (2001). This whiteschist is crosscut by a late Alpine top to the SW-dipping shear zone. The deformation overprints the whiteschist peak metamorphic assemblage, retrograding it locally into a greenschist facies assemblage. This top to the SW dipping shear zone is coherent with the backfolding, which occurred during greenschist facies metamorphism (Steck et al., 2015). The whiteschist is approximately $50 \mathrm{~m}$ long and $15 \mathrm{~m}$ wide, elongated in the NW-SE direction. The whiteschist body is slightly deformed by a schistosity that crosscuts the whiteschist-metagranite transition zones. Some blocks of whiteschist remained undeformed. The crosscutting relationship and associated greenschist overprint clearly shows that the deformation post-dates peak high-pressure metamorphism, as it is also the case for the Mezzalama whiteschist. The peak metamorphic assemblage consists of chloritoid, talc, phengite, quartz, and locally some kyanite is found. The deformed, retrogressed, whiteschist is similar to the Mezzalama whiteschist described from Zone $\mathrm{A}_{\text {out }}$ Zircon, monazite, allanite, tourmaline, rutile, iron oxide and pyrite are accessory minerals. The central part of the whiteschist was altered during pre-high-pressure metasomatism in the vicinity of a vein-like structure, which now contains sulfides, surrounded by a layer of garnet-rich whiteschist.

\section{Whole-rock geochemistry and stable isotope compositions}

The field observations described clearly show that the whiteschists in the Monte Rosa nappe are the result of metasomatic alteration of the granite protolith, in agreement with the interpretations of Pawlig and Baumgartner (2001). This conclusion was also reached by Marger et al. (2019), based on a comparative study of oxygen isotope and major-element compositions of tourmaline found both in whiteschists and metagranites. Below, we present whole-rock chemical and isotopic data on the granite protolith and its metasomatic alteration, the whiteschist.

To estimate the compositional variations due to the alteration of the granite protolith, the ISOCON method was used (Grant 1986), combined with the least-squares approach of Baumgartner and Olsen (1995). It is worth noting here that any mass balance calculation requires additional constraints, as discussed in detail by Gresens (1967). He showed that enrichment in an element, $i$, can be obtained through a decrease of another element in the rock, even if element $i$ was not at all transported; inversely, the concentration of element $i$ can decrease in a metasomatic rock solely due to addition of another element $j$. Indeed, it is easy to show that, besides density and element concentrations of the altered 

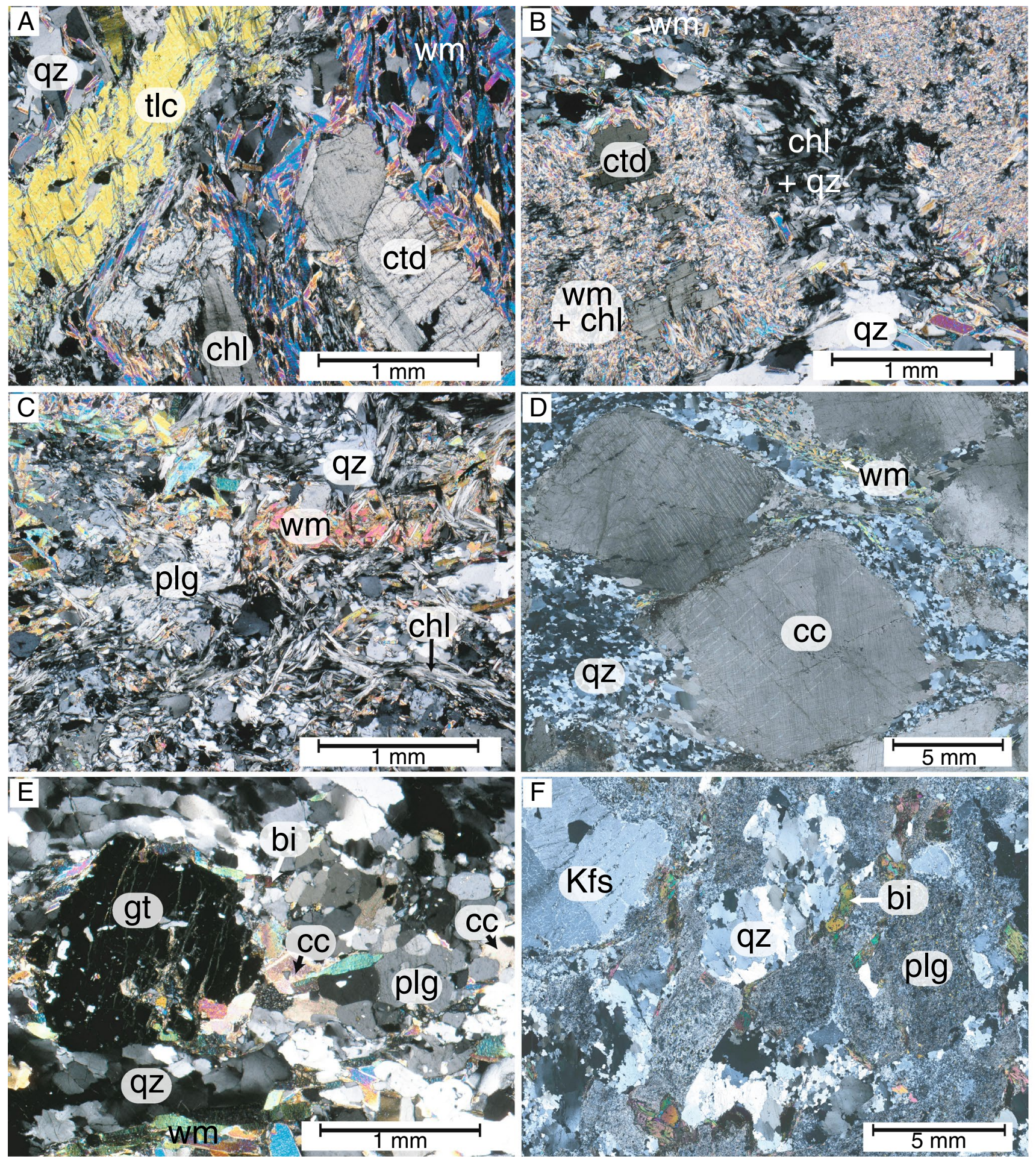

and initial rocks, one additional equation is needed to mathematically obtain a unique solution (Gresens 1967; Grant 1986; Baumgartner and Olsen 1995; Ague and Haren 1996; Mukherjee and Gupta 2008). Typical assumptions leading to this additional equation might include constant volume or immobile elements such as Al or $\mathrm{Zr}$ (Dipple et al. 1990;
Baumgartner and Olsen 1995; Ague 2003). The ISOCON approach by Baumgartner and Olsen (1995) uses a statistical approach. First, the variability of the protolith and metasomatic rock is established through multiple compositional analysis. The variance of the mean is then used to establish all possible element combinations, which are, within 
४Fig. 5 Thin section pictures illustrating the main petrographic characteristics of the different rock types found along the transition zone from the whiteschist to the porphyritic metagranite. Most of the rocks belonging to the Mezzalama whiteschist are undeformed or have been only slightly deformed during a post peak-pressure deformation event. a Zone $\mathrm{A}_{\text {in }}$ (inner whiteschist); ctd, tlc, wm, chl and qz mark the well-preserved high pressure paragenesis (sample 14MR7). b Zone $\mathrm{A}_{\text {out }}$ (outer whiteschist); ctd and tlc are partially to completely replaced by fine-grained chl and wm during the greenschist-facies, late Alpine retrogression. The outlines of ctd and tlc pseudomorphs are still visible. $\mathrm{Chl}$ is becoming more abundant in samples towards the outer parts of the whiteschist. c zone B; plagioclase porphyroblasts embed chl, wm and qz. d zone $\mathrm{C}$; cc and qz vein, with small amount of wm; e zone C; greenschist-facies metagranite with interstitial matrix cc, plg, wm, qz, gt and bi; f Porphyritic metagranite, mostly undeformed, containing igneous Kfs, plg (pseudomorphosed by a fine-grained aggregate of zoisite, albite and white mica), bi, qz and fine-grained gt. Mineral abbreviations are: bi: biotite, cc: calcite, chl: chlorite, ctd: chloritoid, gt: garnet, Kfs: K-feldspar, plg: plagioclase, qz: quartz, tlc: talc, wm: white mica

the uncertainty of their concentrations, compatible as a set of immobile elements (Online Supplementary material S1). This approach is based on the principle that alteration of a rock will remove or add elements that are highly mobile, while other elements are considered to be immobile. The larger the group of elements is that behaves in a similar fashion, the more likely it is that they can be interpreted as immobile elements by this statistical approach. In addition, in the case of several possibilities, a set of immobile elements should be selected based on past studies that have suggested that certain elements are immobile (e.g., Al, Zr, Ti, etc.), adding geochemical knowledge to the statistical interpretation. For more detail, the reader is referred to Baumgartner and Olsen (1995). The results of the calculations can be graphically illustrated in an ISOCON diagram, in which the concentration of the elements in the unaltered rocks is plotted versus that of elements in the altered rock (Grant, 1986; Fig. 6). Here, we chose a logarithmic representation. Note that an ISOCON line, connecting the elements considered to be immobile, has a slope of one in this logarithmic diagram, while the $\mathrm{y}$-axis value at $\log \left(\mathrm{c}^{0}\right)=0$ is the mass change in the system (Baumgartner and Olsen 1995). Note that error bars are on a log scale and, therefore, are asymmetric or smaller than the marker size. The line defining the ISOCON passes through all immobile elements within the uncertainty, that is elements that are assumed not to change their concentration during alteration.

A total of 4 porphyritic metagranites, 3 samples from Zone B, 4 whiteschists from the Zone $\mathrm{A}_{\text {out }}$, and 8 whiteschists from Zone $\mathrm{A}_{\text {in }}$ were selected, all from the Mezzalama area, for bulk rock major- and trace-element measurements (Tables 2, 3). 83 possible combinations of immobile elements are proposed by the ISOCON software (Baumgartner and Olsen 1995). The 25th first proposition of a combination of elements are listed as example in Online Supplemetary material S1. The chosen combination of immobile elements for the alteration of the metagranite-to-whiteschist zone $\mathrm{A}_{\text {in }}$ is: $\mathrm{Al}_{2} \mathrm{O}_{3}, \mathrm{FeO}, \mathrm{Fe}_{2} \mathrm{O}_{3}, \mathrm{TiO}_{2}$, and $\mathrm{P}_{2} \mathrm{O}_{5}$ as major elements, and $\mathrm{Sc}, \mathrm{Ni}, \mathrm{Y}, \mathrm{Zr}, \mathrm{Nb}$, Mo, La, Ce, Pr, Nd, Sm, Eu, Gd, Tb, Dy, Ho, Er, Tm, Yb, Lu, Hf, Th, and U as immobile trace elements. There is another solution to the ISOCON with the same number of elements, which results in $\mathrm{Al}_{2} \mathrm{O}_{3}$ being slightly mobile, while $\mathrm{SiO}_{2}$ becomes immobile. The results are very similar with respect to the mobile elements, but show a slightly different overall mass balance. The Alconserved scheme results in a $5 \pm 5 \%$ mass gain, while a silica immobile reference frame results in a $10 \pm 5 \%$ mass gain. Note that we do not use volume changes, since the volume of a rock depends on the mineralogy of the alteration process. Since the mineralogy changed during Alpine metamorphism, it is not possible to determine volume change without knowing the initial metasomatic mineralogy.

The results indicate an enrichment in $\mathrm{MgO}$ and $\mathrm{H}_{2} \mathrm{O}$ and a depletion of $\mathrm{Na}_{2} \mathrm{O}, \mathrm{CaO}, \mathrm{Cu}, \mathrm{Pb}, \mathrm{Zn}, \mathrm{Sr}$, and $\mathrm{Ba}$ to obtain the whiteschist from a granitic precursor. The results obtained agree with the previous ISOCON study from Vera whiteschist locality, which was studied by Pawlig and Baumgartner (2001), who found a mass gain of $17 \pm 6 \%$ for the granite-to-whiteschist alteration. Their study revealed the same trends, with $\mathrm{MgO}$ and $\mathrm{H}_{2} \mathrm{O}$ enrichment and $\mathrm{CaO}$, $\mathrm{Na}_{2} \mathrm{O}$ depletion as well as immobile $\mathrm{K}_{2} \mathrm{O}$. Hence, the two whiteschist outcrops were altered by fluids of a very similar chemical composition.

The relative enrichment in $\mathrm{MgO}$ and depletion in $\mathrm{CaO}$ and $\mathrm{Na}_{2} \mathrm{O}$ indicate that the fluid responsible for the metasomatic alteration of the granite was oversaturated in $\mathrm{MgO}$, leading to $\mathrm{MgO}$ precipitation, and it was undersaturated in $\mathrm{CaO}$ and $\mathrm{Na}_{2} \mathrm{O}$, resulting in leaching of these elements from the granite. As $\mathrm{K}_{2} \mathrm{O}$ and $\mathrm{SiO}_{2}$ behave as immobile elements in the Vera whiteschist and the Mezzalama whiteschist, respectively, the fluid was saturated in these elements. A similar ISOCON plot was made for whiteschists belonging to Zone $\mathrm{A}_{\text {out }}$ resulting in a similar compositional trend, only $\mathrm{Fe}_{2} \mathrm{O}_{3}$ is somewhat lower in the metasomatic rock than in the granite protolith (Fig. 6c). This pattern reflects a similar fluid to be responsible for the composition of external parts of Zone $\mathrm{A}$. Since zone $\mathrm{A}_{\text {out }}$ and zone $\mathrm{A}_{\text {in }}$ are very similar in original mineralogy, and the main difference is the greenschist facies overprint, this confirms that no major mass transport occurred during the late greenschist facies Alpine overprint.

ISOCON plots were made for rocks from Zone B (Fig. 7), which are intermediate between metagranites and whiteschists (Fig. 3c). Their composition was compared to the metagranite (Fig. 7A) and to the whiteschist (Fig. 7b). The results show that rocks from Zone B are closer in composition to the whiteschist (Fig. 6a) as they share the same compositional characteristics with an enrichment in $\mathrm{MgO}$ 

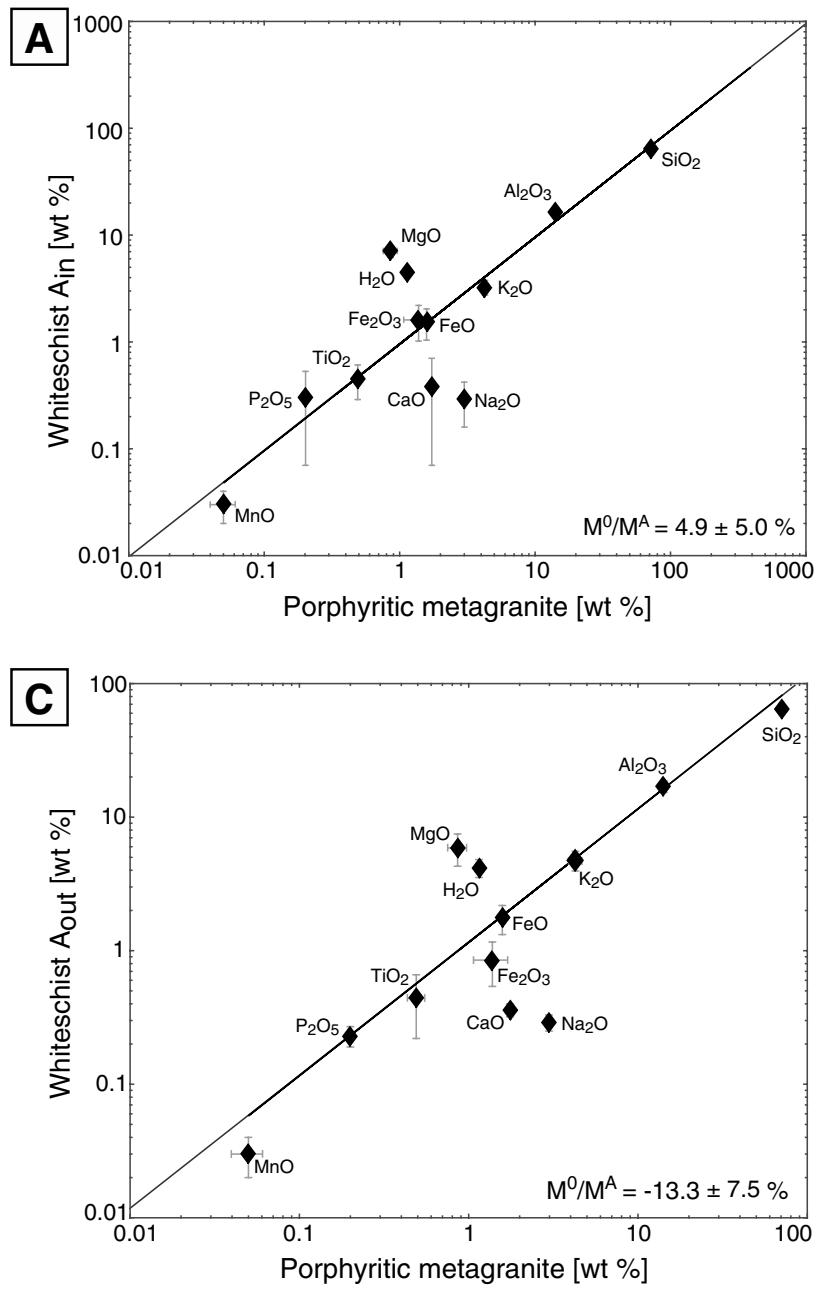

Fig. 6 a ISOCON diagram showing the porphyritic metagranite composition plotted against the Mezzalama whiteschist composition in the centre of the whiteschist (Zone $\mathrm{A}_{\text {in }}$ ). Compositions are in wt\% for major elements. A mass change of $4.9 \pm 5.0 \%$ is calculated using the following combination of immobile elements: $\mathrm{Al}_{2} \mathrm{O}_{3}, \mathrm{FeO}, \mathrm{Fe}_{2} \mathrm{O}_{3}$, $\mathrm{TiO}_{2}$, and $\mathrm{P}_{2} \mathrm{O}_{5}$. b Result of the same calculation for trace elements, in ppm. Mobile trace elements are highlighted with filled symbols. c ISOCON diagram for major elements of the granite protolith ver-

and $\mathrm{H}_{2} \mathrm{O}$ and depletion in $\mathrm{CaO}$ as well as $\mathrm{Fe}_{2} \mathrm{O}_{3}$. The similarity with the whiteschist from Zone A indicates that Zone B results from the alteration of the granite by the same fluid. However, rocks from Zone $\mathrm{B}$ have $\mathrm{Na}_{2} \mathrm{O}$ concentrations closer to the composition of the metagranite, and hence, the composition of the fluids becomes saturated in sodic plagioclase as the fluid reacted with the granite.

Whole-rock composition of 29 samples collected on a profile from the Mezzalama whiteschist to the porphyritic metagranite and the whiteschist at the contact with the paragneiss were measured (Table 4). The profile is shown in Fig. $3 \mathrm{~d}$ by the red line. Based on the mass balance considerations above, the oxides $\mathrm{MgO}, \mathrm{Na}_{2} \mathrm{O}, \mathrm{CaO}, \mathrm{K}_{2} \mathrm{O}$ as well as

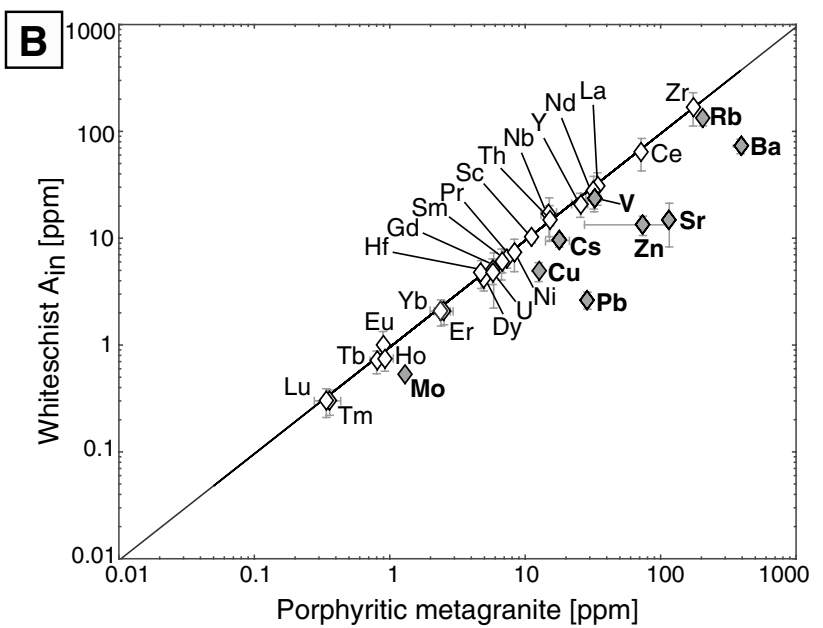

sus the external part of the whiteschist $\left(\right.$ Zone $\left.A_{\text {out }}\right)$. A mass change of $-13.3 \pm 7.5 \%$ is calculated. Note that all scales are logarithmic, as well as error bars. Error bars represent the standard deviation of the mean on the $\mathrm{n}$ analyses considered for both the granite and whiteschist (1SD). In both whiteschists (inner and outer), $\mathrm{MgO}$ and $\mathrm{H}_{2} \mathrm{O}$ are enriched, $\mathrm{CaO}$ and $\mathrm{Na}_{2} \mathrm{O}$ are leached. This implies a fluid oversaturated in $\mathrm{MgO}$ and undersaturated in $\mathrm{CaO}$ and $\mathrm{Na}_{2} \mathrm{O}$

$\mathrm{H}_{2} \mathrm{O}$ are plotted. Figure 8a illustrates that the sodium front is located at the $\mathrm{A} / \mathrm{B}$ zone boundary, while the $\mathrm{MgO}$ and $\mathrm{CaO}$ fronts are located at the $\mathrm{B} / \mathrm{C}$ zone boundary. The stepwise changes along mineralogical fronts are characteristics of chromatographic alteration fronts in metasomatic environments described by the chromatographic theory (Korzhinskii 1968; Steefel and MacQuarrie 1996).

$\delta^{18} \mathrm{O}$ and $\delta \mathrm{D}$ values were measured on 14 samples from this profile (Table 5). A distance versus $\delta^{18} \mathrm{O}$ (Fig. 8b, left vertical scale) and $\delta \mathrm{D}$ values (Fig. $8 \mathrm{~b}$, right vertical scale) plot shows that the isotopic compositions were changed throughout zones $\mathrm{A}_{\text {out }}$ to $\mathrm{C}$, but have constant values in the metagranite and in most of the samples in zone $\mathrm{A}_{\mathrm{in}}$. 


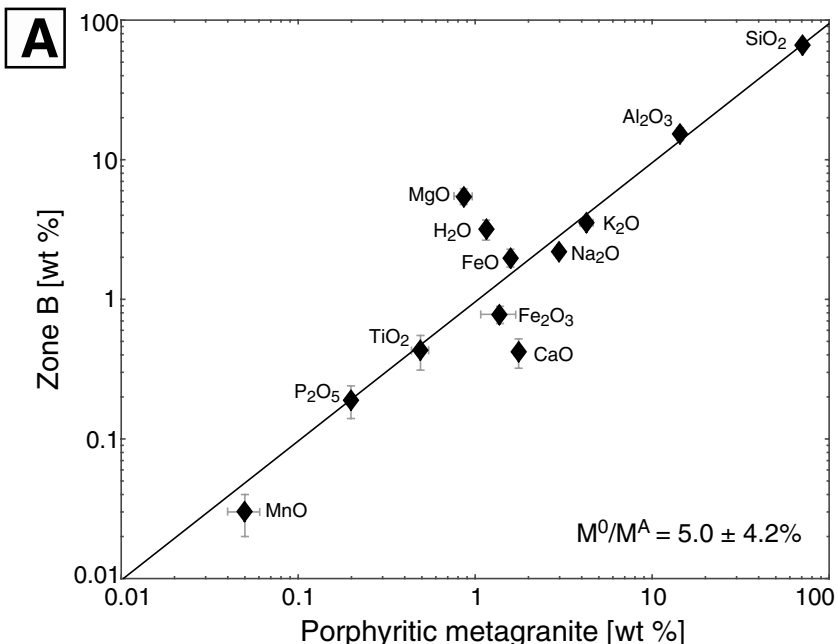

Fig. 7 ISOCON diagram showing the averaged porphyritic metagranite composition plotted against zone B (a) and against Mezzalama whiteschist (b). Compositions are in wt\% for major elements. Note that the scale is logarithmic, as well as error bars. Error bars represent the standard deviation of the mean on the $\mathrm{n}$ analyses, reported in Table 2a, considered for both the metagranite and whiteschist (1SD).

The $\delta^{18} \mathrm{O}$ values of ca. $11.5 \%$ of the granite are typical for S-type granites (Harris et al. 1997). The stable isotope compositions decrease by about $3 \%$ for $\delta^{18} \mathrm{O}$ and increase by $20 \%$ or for $\delta \mathrm{D}$ from metagranite to the whiteschist, suggesting that the system was at least partially fluid buffered. This is also suggested by the fact that whiteschists from both locations (Mezzalama and Boundary) have similar $\delta^{18} \mathrm{O}$ and $\delta \mathrm{D}$ values.

\section{Carbonate stable isotope compositions}

Calcite is found in both the Mezzalama whiteschist and the Vera whiteschist. In the Mezzalama area, they appear in Zone $\mathrm{C}$ of the transition zone, either as veins or as matrix carbonate. The carbonate is calcite in all cases.

$\delta^{13} \mathrm{C}$ and $\delta^{18} \mathrm{O}$ values have been measured on six samples of carbonate veins and carbonate-bearing whiteschists from the Mezzalama area. Results are given in Table 6 together with those from 5 samples of the Vera whiteschist (Pawlig and Baumgartner 2001) for comparison. Mezzalama carbonates have a range from -7.6 to $-6.7 \%$ in $\delta^{13} \mathrm{C}$ and from 9.3 to $10.8 \%$ in $\delta^{18} \mathrm{O}$. Carbonates from Vera whiteschist from Pawlig and Baumgartner (2001) have a range from -9.8 to $-9.6 \%$ in $\delta^{13} \mathrm{C}$ and 9.6 to $10.1 \%$ in $\delta^{18} \mathrm{O}$. Carbonates from the Mezzalama whiteschist have slightly higher $\delta^{13} \mathrm{C}$ than the Vera whiteschist, for comparable $\delta^{18} \mathrm{O}$. A plot of these isotopic compositions in a $\delta^{13} \mathrm{C}$ versus $\delta^{18} \mathrm{O}$ diagram (Fig. 9) supports a

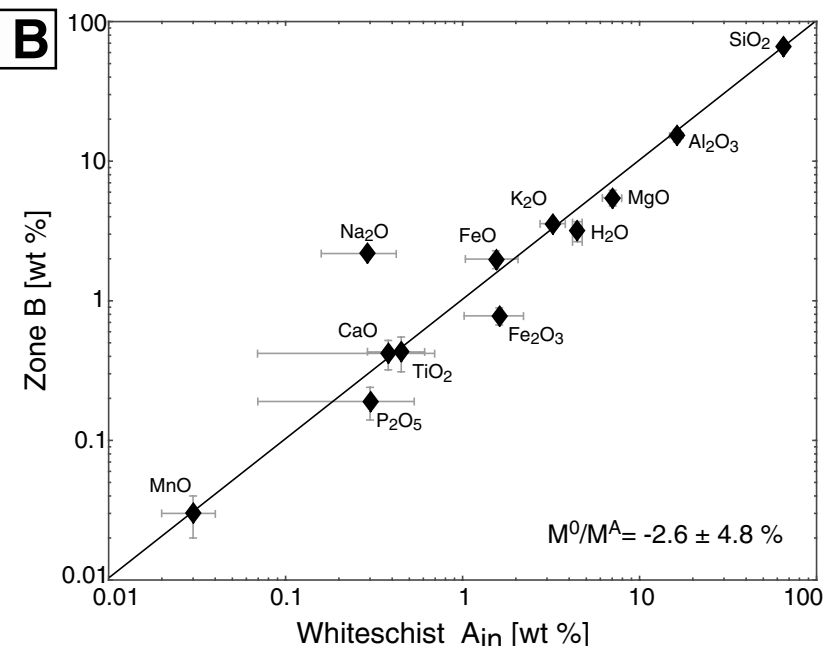

The alteration which produced zone $\mathrm{B}$ is similar to that of the whiteschist of zone A (Fig. 6a, c), except for $\mathrm{Na}_{2} \mathrm{O}$, that was enriched relatively to the whiteschist of zone A. Apparently, the alteration fluid become saturated in albite, resulting in a Na-rich rim surrounding the whiteschist

magmatic origin (Valley 1986; Hoefs 1987; Pawlig and Baumgartner 2001).

\section{Rb- and Sr-isotope compositions}

Several metagranites and whiteschists from the Mezzalama area have been selected for strontium $(\mathrm{Sr})$ isotope analyses. Since the $\mathrm{Rb} / \mathrm{Sr}$ ratios are much higher in the whiteschist than those of the granite, we expected to be able to determine the age of the hydrothermal alteration using a classical $\mathrm{Rb} / \mathrm{Sr}$ isochrone. Whiteschist are from Zone $\mathrm{A}_{\text {in }}$ (Table 1). The metagranites were collected from various parts of the study area and are undeformed metagranites. As shown in Fig. $6 \mathrm{~b}, \mathrm{Sr}$ was one of the most mobile elements during metasomatism of the granite. It was depleted along with $\mathrm{Ca}$. In contrast, rubidium $(\mathrm{Rb})$ behaves geochemically similar to potassium and was hence little affected by the metasomatism. Depending on the $\mathrm{Rb} / \mathrm{Sr}$ of a rock, the isotopic ratios of ${ }^{87} \mathrm{Rb} /{ }^{86} \mathrm{Sr}$ and ${ }^{87} \mathrm{Sr} /{ }^{86} \mathrm{Sr}$ will have evolved differently. The larger the $\mathrm{Rb} / \mathrm{Sr}$ ratio, the larger the change in ${ }^{87} \mathrm{Sr} /{ }^{86} \mathrm{Sr}$ with time. Ideally, one would obtain a $\mathrm{Rb} / \mathrm{Sr}$ isochron if the system remained closed after metasomatism.

The ${ }^{87} \mathrm{Sr} /{ }^{86} \mathrm{Sr}$ ratios, in combination with $\mathrm{Rb}$ and $\mathrm{Sr}$ (ppm) content, were used to calculate ${ }^{87} \mathrm{Rb} /{ }^{86} \mathrm{Sr}$ ratios (Table 7; details in analytical methods) and plotted in a ${ }^{87} \mathrm{Rb} /{ }^{86} \mathrm{Sr}$ versus ${ }^{87} \mathrm{Sr} /{ }^{86} \mathrm{Sr}$ diagram (Fig. 10). Data from the Mezzalama whiteschists were compared with data from the Vera whiteschists (Pawlig 2001). Metagranites from the Mezzalama and Vera have similar ${ }^{87} \mathrm{Rb} /{ }^{86} \mathrm{Sr}$ and ${ }^{87} \mathrm{Sr} /{ }^{86} \mathrm{Sr}$ ratios, reflecting 

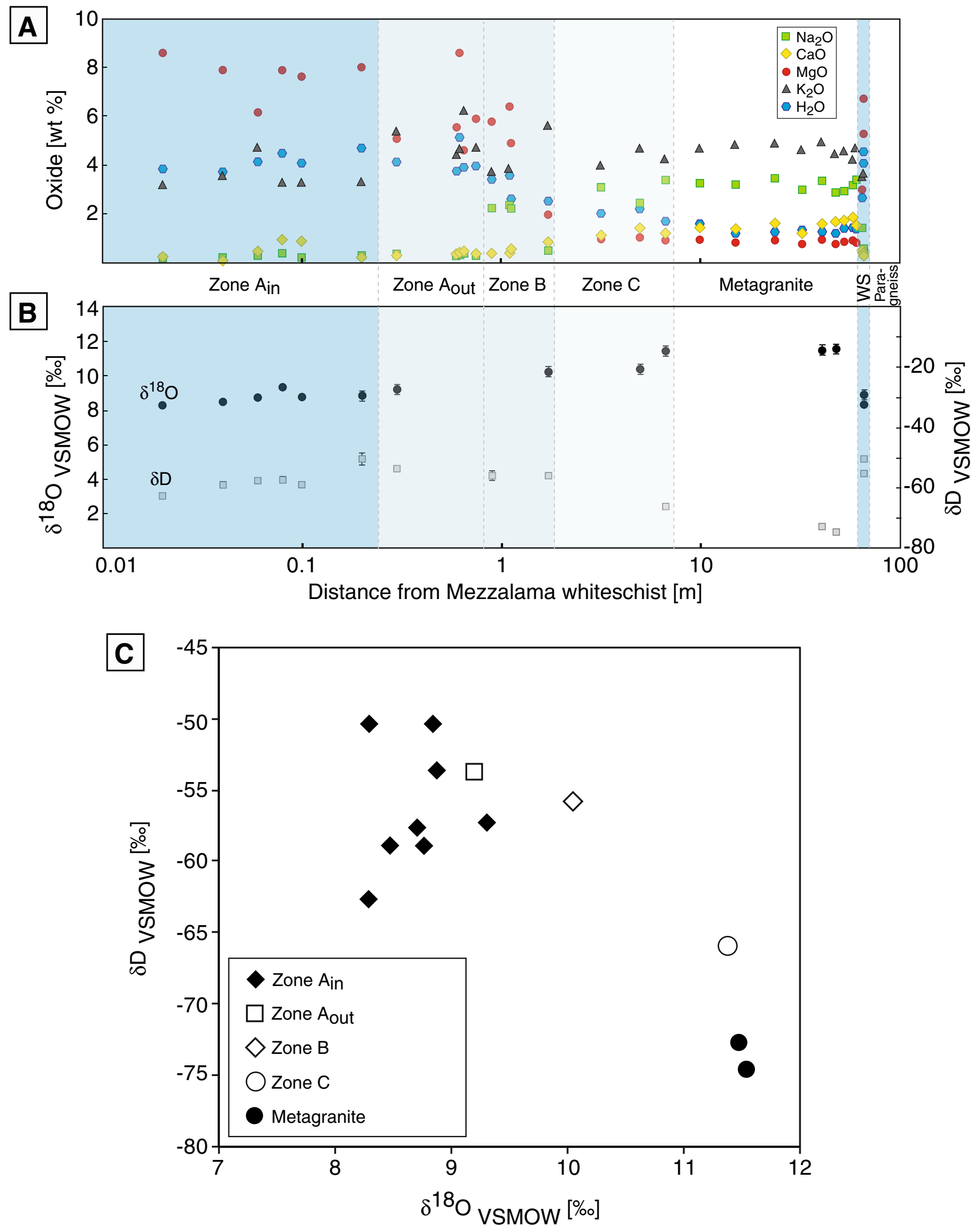
4Fig. 8 a Whole rock composition of samples for the profile sampled at Mezzalama, from the whiteschist towards the contact of the metagranite with the country rock paragneisses, where a second, small whiteschist occurs (red line on Fig. 3d). The mobile elements identified in Fig. 6 and $7\left(\mathrm{CaO}, \mathrm{Na}_{2} \mathrm{O}, \mathrm{MgO}\right.$ and $\mathrm{H}_{2} \mathrm{O}$ content (wt\%)) are shown as a function of distance. Note that $\mathrm{K}_{2} \mathrm{O}$ does not change across the reaction front. $\mathbf{b} \delta \mathrm{D}$ and $\delta^{18} \mathrm{O}$ versus distance. $\mathbf{c} \delta \mathrm{D}$ versus $\delta^{18} \mathrm{O}$ for the same samples as (b) showing two distinct isotopic signatures, with high $\delta \mathrm{D}$ and low $\delta^{18} \mathrm{O}$ for whiteschists and low $\delta \mathrm{D}$ and high $\delta^{18} \mathrm{O}$ for metagranites. Note that the stable isotope fronts have penetrated further into the granite than the chemical alteration fronts. The whiteschist at the contact has the same isotopic composition as the main Mezzalama body

the igneous values of a rather homogeneous metagranite. The isotopic ratios of the granitic gneiss of the Vera area have a range from granitic values towards the measured whiteschist values and whiteschists from both areas have a similar ${ }^{87} \mathrm{Rb} /{ }^{86} \mathrm{Sr}$ range. However, whiteschists from the Mezzalama area always have lower ${ }^{87} \mathrm{Sr} /{ }^{86} \mathrm{Sr}$ than whiteschists from Vera, for similar ${ }^{87} \mathrm{Rb} /{ }^{86} \mathrm{Sr}$. The large range in both ${ }^{87} \mathrm{Rb} /{ }^{86} \mathrm{Sr}$ and ${ }^{87} \mathrm{Sr} /{ }^{86} \mathrm{Sr}$ in all whiteschists reflects the varying $\mathrm{Rb} / \mathrm{Sr}$ ratios resulting from the metasomatic alteration of the granite.

The resulting trends are clear, but unfortunately not linear, which precludes the use of the data for an isochron. It is well established that curved lines, as the one obtained for the present data set in Fig. 10, are typical for systems affected by multiple events; the isochron has been disturbed by later processes (e.g., Faure and Powell 1972).

\section{Discussion}

The field observations showed that: (i) the transition from whiteschist to metagranite is characterized by two zones, which have sharp mineralogical boundaries, (ii) the disappearance of K-feldspar from the igneous protolith towards the whiteschist is sharp and outlines a lobate boundary, while igneous quartz aggregates and crystals can be traced into the whiteschist zones; (iii) straight, undeformed pegmatite and aplite dykes crosscut the granite-whiteschist transition. The mass balance calculations performed above show that over 20 trace- and rare-earth elements, as well as $\mathrm{Ti}$ and $\mathrm{Al}$ can be considered to be immobile, when the whiteschist and granite are compared. This all confirms that the protolith of the whiteschist was indeed the granite. Pawlig and Baumgartner (2001) came to the same conclusion for the Vera whiteschist outcrop, where they suggested that two different granites were involved in the formation of slightly different whiteschist lithologies. Finally, Marger et al. (2019) demonstrated that tourmaline in the whiteschists has cores that correspond in zonation, major-element composition, and $\delta^{18} \mathrm{O}$ value to tourmaline in the adjacent granite for the Vera whiteschists. The field observations thus confirm that the whiteschists are metasomatic alteration zones within the granite. Hence, this further supports that both for the Vera and the Mezzalama whiteschists in the Monte Rosa nappe the protoliths are the granites.

\section{Timing of the metasomatic event}

Unfortunately, the $\mathrm{Rb} / \mathrm{Sr}$ data do not define an isochron. The data form a curved array, suggesting that multiple metamorphic events influenced the $\mathrm{Rb} / \mathrm{Sr}$ systematics. Hence, no precise age for the metasomatism can be defined. The strontium evolution diagram can, however, be used to obtain further information on the metamorphic evolution of the rocks concerned. Results of both this study as well as that of Pawlig (2001) are shown in Fig. 11. The ${ }^{87} \mathrm{Sr} /{ }^{86} \mathrm{Sr}$ ratios are homogeneous for the granite (0.7331-0.7358), indicated by the heavy line in Fig. 11 . The ${ }^{87} \mathrm{Sr} /{ }^{86} \mathrm{Sr}$ evolution is also calculated back to $270 \mathrm{Ma}$, the age of the granite (Pawlig 2001), using today's $\mathrm{Rb} / \mathrm{Sr}$ elemental ratio for the Monte Rosa granite. Unaltered granite evolved along this line with time. In a simple model, in which one metasomatic event increased the $\mathrm{Rb} / \mathrm{Sr}$ ratio by decreasing the $\mathrm{Sr}$ concentration, as indicated by the mass balance calculations (without fractionation of the isotopes), one would expect one intersection for all whiteschist sample evolution lines with the granite evolution line; the intersection would define the age of the metasomatic event. Since the model whiteschist contains significantly more $\mathrm{Rb}$, the radiogenic daughter, ${ }^{87} \mathrm{Sr}$, would show a larger increase and plot above the granite evolution line, yielding the high ${ }^{87} \mathrm{Sr} /{ }^{86} \mathrm{Sr}$ measured today. Of course, the same age should be obtained, as defined by the isochron in a traditional ${ }^{87} \mathrm{Sr} /{ }^{86} \mathrm{Sr}$ versus ${ }^{87} \mathrm{Rb} /{ }^{86} \mathrm{Sr}$ diagram for a closed system. However, as this is not the case, the system was disturbed, resulting in multiple intersections with the granite for the various whiteschist samples. Nevertheless, all intersection points are older than the Alpine high-pressure metamorphism. They span about $200 \mathrm{Ma}$, from $80 \mathrm{Ma}$ to $280 \mathrm{Ma}$. Alternatively, if a single, pervasive event homogenised the ${ }^{87} \mathrm{Sr} /{ }^{86} \mathrm{Sr}$ composition of the whiteschist after metasomatism - such as the prograde high-pressure metamorphic overprint—one would expect intersection of all ${ }^{87} \mathrm{Sr} /{ }^{86} \mathrm{Sr}$ evolution lines well above the granite evolution line, indicating the age of the homogenisation event. While multiple samples do intersect each other, no clear pattern evolves. Nevertheless, all whiteschist samples indicate that alteration occurred well before the Alpine metamorphism. The intersections in the age range of the Alpine metamorphism for several of the whiteschist samples could indicate a partial homogenization during devolatilization reactions during the prograde path of the Alpine high-pressure metamorphism.

A less likely, but possible alternative is that high ${ }^{87} \mathrm{Sr} /{ }^{86} \mathrm{Sr}$ could have been imposed from the alteration fluids; alternatively, a multiphase evolution, with a partial homogenization 


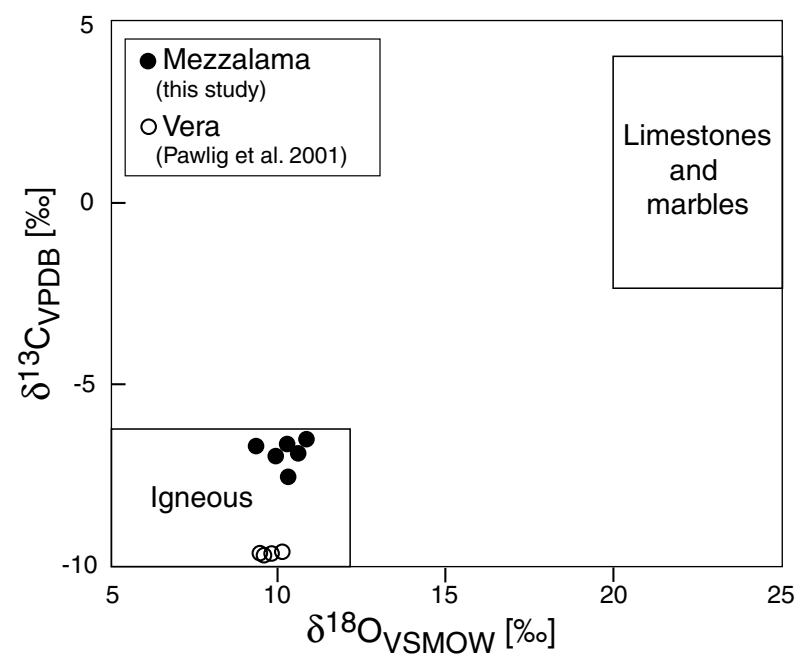

Fig. $9 \delta^{13} \mathrm{C}$ and $\delta^{18} \mathrm{O}$ isotopic compositions of calcite from Zone $\mathrm{C}$ in Mezzalama area (data in Table 6), indicating an igneous carbon source for both whiteschist outcrops. Data for the Vera outcrop come from Pawlig and Baumgartner (2001). Data for isotopic values of sedimentary carbonates and igneous carbonates are from Valley (1986) and Hoefs (1987)

could also yield these results. In this scenario, the rocks were infiltrated by fluids, carrying significant but variable amounts of radiogenic strontium. Typical sources of such radiogenic strontium would be an old crustal reservoir, such as the metapelites in the basement making up the host rocks of the Monte Rosa granite (Faure 1998).

We conclude that the strontium isotopic system was disturbed during the Alpine history, due to recrystallization and potential post-peak re-equilibration with fluids. Based on the strontium isotopic data, it is also clear that whiteschist alteration occurred prior to the Alpine metamorphism. The fact that all intersections are above the granite evolution line, e.g., the whiteschists have higher ${ }^{87} \mathrm{Sr} /{ }^{86} \mathrm{Sr}$ ratios, requires that a significant amount of time elapsed between alteration and partial homogenisation due to Alpine metamorphism, such that rocks with high $\mathrm{Rb} / \mathrm{Sr}$ ratios could evolve towards high radiogenic ${ }^{87} \mathrm{Sr}$. This alteration could have occurred during a late magmatic hydrothermal stage, shortly after emplacement of the granite, and during its cooling. This interpretation is in line with the results of Marger et al. (2019), and Pawlig and Baumgartner (2001), who showed, on the basis of microtextural relationships and tourmaline compositions, that the metasomatic alteration of the granite occurred before the onset of the Alpine metamorphism. However, due to the heavy Alpine metamorphic overprint, we cannot exclude that the metasomatism occurred later during the Mesozoic evolution of the Monte Rosa basement, yet still prior to the Alpine orogeny.

\section{Nature of the metasomatic fluid altering the granite}

Our new data based on field observations, radiogenic isotope compositions, and timing of the metasomatic alteration in the Monte Rosa nappe, as well as the stable isotope and whole-rock compositions require a pre-Alpine alteration. Considering the geologic history of the Monte Rosa nappe, we further consider two possible alternative scenarios: I) either seawater incursion during Mesozoic extension (e.g., Manatschal et al. 2000) or II) magmatic-hydrothermal fluids (Pawlig and Baumgartner 2001). Metasomatism by seawater fluids would occur during the Mesozoic extension, leading to the opening of the Piemont oceanic basin (Trümpy 1980). As part of the distal margin of the Briançonnais microcontinent (Steck et al. 2014), the Monte Rosa basement rocks are exposed along the ocean-continent transition. In this tectonic setting, seawater fluids could penetrate and locally interact with ultramafic rocks exhumed at the seafloor and
Table 1 Mineral mode (in vol\%), estimated from petrographic observations for samples from each zone of the metagranite to whiteschist transition in the Mezzalama area (see Fig. 3C for zone delimitation)

\begin{tabular}{llllll}
\hline Minerals vol\% & $\begin{array}{l}\text { Zone } \mathrm{A}_{\text {in }} \\
\text { Whiteschist }\end{array}$ & $\begin{array}{l}\text { Zone } \mathrm{A}_{\text {out }} \\
\text { Whiteschist }\end{array}$ & $\begin{array}{l}\text { Zone B } \\
\text { Plagioclase zone }\end{array}$ & $\begin{array}{l}\text { Zone C } \\
\text { Carbonate zone }\end{array}$ & $\begin{array}{l}\text { Metagranite } \\
\text { Porphyritic metagranite }\end{array}$ \\
\hline Talc & $10-25$ & - & - & - & - \\
Chloritoid & $20-25$ & $0-10$ & - & - & - \\
Mg-chlorite & $0-5$ & $30-50$ & $30-50$ & - & - \\
Plagioclase & - & - & $10-20$ & $10-20$ & 30 \\
Carbonate & - & - & - & $10-20$ & - \\
Biotite & - & - & - & $0-20$ & 15 \\
Garnet & - & - & - & $0-20$ & 1 \\
K-feldspar & - & - & - & - & 30 \\
Phengite & $20-30$ & $20-50$ & $20-50$ & $20-30$ & 4 \\
Quartz & $10-40$ & $10-40$ & $10-40$ & $10-30$ & 20 \\
\hline
\end{tabular}

Zones $\mathrm{A}_{\text {in }}$ and $\mathrm{A}_{\text {out }}$ have very similar mineralogy and modes, with the exception of retrograde chlorite replacing talc and partially chloritoid, due to greenschist facies, late Alpine overprint. The variability of the reported volume estimates here is due to the natural variability of multiple samples from each zone 
Table 2 Major element compositions in wt\% of the metagranites, whiteschists (inner part), whiteschist (outer part) and rocks of the transition zone B from the Mezzalama area

\begin{tabular}{|c|c|c|c|c|c|c|c|c|c|c|c|c|c|}
\hline $\begin{array}{l}\text { Porphyritic meta- } \\
\text { granites }\end{array}$ & $\mathrm{SiO}_{2}$ & $\mathrm{TiO}_{2}$ & $\mathrm{Al}_{2} \mathrm{O}_{3}$ & $\mathrm{Fe}_{2} \mathrm{O}_{3}$ & $\mathrm{FeO}$ & $\mathrm{MnO}$ & $\mathrm{MgO}$ & $\mathrm{CaO}$ & $\mathrm{Na}_{2} \mathrm{O}$ & $\mathrm{K}_{2} \mathrm{O}$ & $\mathrm{P}_{2} \mathrm{O}_{5}$ & $\mathrm{H}_{2} \mathrm{O}$ & Total \\
\hline $14 \mathrm{MR} 51 *$ & 71.99 & 0.43 & 13.77 & 1.08 & 1.59 & 0.05 & 0.75 & 1.62 & 2.81 & 4.36 & 0.19 & 1.18 & 99.81 \\
\hline $15 \mathrm{MR} 31 *$ & 70.63 & 0.48 & 14.38 & 1.38 & 1.56 & 0.05 & 0.85 & 1.75 & 3.04 & 4.40 & 0.20 & 1.09 & 99.80 \\
\hline $15 \mathrm{MR} 38 *$ & 70.83 & 0.48 & 14.24 & 1.25 & 1.61 & 0.05 & 0.85 & 1.69 & 2.95 & 4.57 & 0.20 & 1.08 & 99.79 \\
\hline 15MR39* & 70.30 & 0.55 & 14.44 & 1.79 & 1.57 & 0.07 & 0.99 & 1.93 & 3.12 & 3.74 & 0.22 & 1.23 & 99.95 \\
\hline Average & 70.93 & 0.49 & 14.21 & 1.38 & 1.58 & 0.05 & 0.86 & 1.75 & 2.98 & 4.27 & 0.20 & 1.15 & 99.84 \\
\hline $1 \mathrm{SD}$ & 0.74 & 0.05 & 0.31 & 0.30 & 0.02 & 0.01 & 0.10 & 0.13 & 0.13 & 0.36 & 0.01 & 0.07 & 0.08 \\
\hline Whiteschist, inner & $\mathrm{SiO}_{2}$ & $\mathrm{TiO}_{2}$ & $\mathrm{Al}_{2} \mathrm{O}_{3}$ & $\mathrm{Fe}_{2} \mathrm{O}_{3}$ & $\mathrm{FeO}$ & $\mathrm{MnO}$ & $\mathrm{MgO}$ & $\mathrm{CaO}$ & $\mathrm{Na}_{2} \mathrm{O}$ & $\mathrm{K}_{2} \mathrm{O}$ & $\mathrm{P}_{2} \mathrm{O}_{5}$ & $\mathrm{H}_{2} \mathrm{O}$ & Total \\
\hline $15 \mathrm{MR} 30 *$ & 62.38 & 0.47 & 17.13 & 2.39 & 1.62 & 0.04 & 8.24 & 0.22 & 0.15 & 3.02 & 0.18 & 4.40 & 100.24 \\
\hline 15MR29* & 63.62 & 0.52 & 16.94 & 2.30 & 1.25 & 0.03 & 7.56 & 0.06 & 0.18 & 3.36 & 0.07 & 4.33 & 100.20 \\
\hline 14MR8* & 62.39 & 0.09 & 18.81 & 1.52 & 1.20 & 0.03 & 5.86 & 0.45 & 0.27 & 4.47 & 0.35 & 4.47 & 99.89 \\
\hline 14MR66* & 62.66 & 0.48 & 16.17 & 1.84 & 1.62 & 0.04 & 7.50 & 0.88 & 0.34 & 3.10 & 0.66 & 4.64 & 99.94 \\
\hline 14MR7* & 65.00 & 0.58 & 15.30 & 1.21 & 1.48 & 0.03 & 7.28 & 0.84 & 0.20 & 3.12 & 0.65 & 4.86 & 100.54 \\
\hline 14MR14* & 64.62 & 0.46 & 15.42 & 0.62 & 2.68 & 0.03 & 7.59 & 0.19 & 0.26 & 3.11 & 0.14 & 4.70 & 99.82 \\
\hline 14MR67* & 66.13 & 0.43 & 15.85 & 1.75 & 1.29 & 0.02 & 6.51 & 0.17 & 0.44 & 3.07 & 0.13 & 4.34 & 100.13 \\
\hline 14MR68* & 68.99 & 0.59 & 14.09 & 1.24 & 1.16 & 0.01 & 5.87 & 0.27 & 0.52 & 2.81 & 0.19 & 3.94 & 99.69 \\
\hline Average & 64.47 & 0.45 & 16.21 & 1.61 & 1.54 & $\mathbf{0 . 0 3}$ & 7.05 & 0.38 & 0.29 & 3.26 & 0.30 & 4.46 & 100.05 \\
\hline $1 \mathrm{SD}$ & 2.27 & 0.16 & 1.43 & 0.59 & 0.50 & 0.01 & 0.87 & 0.31 & 0.13 & 0.51 & 0.23 & 0.28 & 0.27 \\
\hline Whiteschist, outer & $\mathrm{SiO}_{2}$ & $\mathrm{TiO}_{2}$ & $\mathrm{Al}_{2} \mathrm{O}_{3}$ & $\mathrm{Fe}_{2} \mathrm{O}_{3}$ & $\mathrm{FeO}$ & $\mathrm{MnO}$ & $\mathrm{MgO}$ & $\mathrm{CaO}$ & $\mathrm{Na}_{2} \mathrm{O}$ & $\mathrm{K}_{2} \mathrm{O}$ & $\mathrm{P}_{2} \mathrm{O}_{5}$ & $\mathrm{H}_{2} \mathrm{O}$ & Total \\
\hline 14MR16A & 67.70 & 0.40 & 15.27 & 0.94 & 1.45 & 0.02 & 5.31 & 0.33 & 0.27 & 4.20 & 0.21 & 3.75 & 99.85 \\
\hline 14MR16B & 59.52 & 0.68 & 17.69 & 1.25 & 2.19 & 0.04 & 8.13 & 0.38 & 0.29 & 4.39 & 0.23 & 5.12 & 99.90 \\
\hline 14MR16C & 63.55 & 0.13 & 18.94 & 0.64 & 1.32 & 0.02 & 4.42 & 0.41 & 0.35 & 5.95 & 0.30 & 3.88 & 99.91 \\
\hline 14MR17 & 65.98 & 0.42 & 15.94 & 0.56 & 2.05 & 0.03 & 5.64 & 0.33 & 0.27 & 4.47 & 0.20 & 3.94 & 99.83 \\
\hline Average & 64.19 & 0.41 & 16.96 & 0.85 & 1.75 & $\mathbf{0 . 0 3}$ & 5.88 & 0.36 & 0.29 & 4.75 & 0.23 & 4.17 & 99.87 \\
\hline $1 \mathrm{SD}$ & 3.55 & 0.22 & 1.67 & 0.31 & 0.43 & 0.01 & 1.59 & 0.04 & 0.04 & 0.80 & 0.04 & 0.64 & 0.04 \\
\hline Whiteschist, outer & $\mathrm{SiO}_{2}$ & $\mathrm{TiO}_{2}$ & $\mathrm{Al}_{2} \mathrm{O}_{3}$ & $\mathrm{Fe}_{2} \mathrm{O}_{3}$ & $\mathrm{FeO}$ & $\mathrm{MnO}$ & $\mathrm{MgO}$ & $\mathrm{CaO}$ & $\mathrm{Na}_{2} \mathrm{O}$ & $\mathrm{K}_{2} \mathrm{O}$ & $\mathrm{P}_{2} \mathrm{O}_{5}$ & $\mathrm{H}_{2} \mathrm{O}$ & Total \\
\hline 14MR18* & 65.48 & 0.53 & 15.80 & 0.78 & 2.07 & 0.04 & 5.54 & 0.37 & 2.12 & 3.56 & 0.19 & 3.37 & 99.84 \\
\hline 14MR19A & 63.76 & 0.30 & 16.53 & 0.89 & 2.23 & 0.04 & 6.15 & 0.37 & 2.24 & 3.66 & 0.14 & 3.56 & 99.88 \\
\hline 14MR19B & 69.65 & 0.47 & 13.55 & 0.68 & 1.66 & 0.03 & 4.73 & 0.53 & 2.16 & 3.48 & 0.24 & 2.59 & 99.77 \\
\hline Average & 66.30 & 0.43 & 15.29 & 0.78 & 1.99 & 0.04 & 5.48 & 0.42 & 2.18 & 3.57 & 0.19 & 3.17 & 99.83 \\
\hline $1 \mathrm{SD}$ & 3.03 & 0.12 & 1.56 & 0.11 & 0.29 & 0.01 & 0.71 & 0.10 & 0.06 & 0.09 & 0.05 & 0.52 & 0.05 \\
\hline
\end{tabular}

These data were used for mass balance calculations with the statistical ISOCON approach of Baumgartner and Olsen (1995) presented in Figs. 5 and 6. $\mathrm{Fe}_{2} \mathrm{O}_{3}$ and $\mathrm{FeO}$ have been obtained by colorimetric method. Samples with an asterisk symbol were used for $\mathrm{H}_{2} \mathrm{O}$ determination by TC/EA

interact on their way back to the surface with the Monte Rosa basement along large-scale detachment structures (Manatschal et al. 2000; Ferrando 2012). Metasomatism by late magmatic-hydrothermal fluids would occur during the cooling of the granite intrusion in the Permian. In such hydrothermal systems, surface-derived fluids mix with primary magmatic fluids in large-scale fluid convection cells, affecting the basement rocks as a result of the thermal perturbation associated with the igneous intrusion.

An exact determination of the nature of the metasomatic fluids is hampered by the lack of the original alteration phases formed during alteration, since subsequent Alpine metamorphism crystallized new phases. Nevertheless, it is not straightforward to interpret the elemental changes. Indeed, the chemical changes introduced by fluid flowing through the rock are inversely proportional to the concentration changes observed in the fluid responsible for alteration along its flow direction (Phillips 1990); for more detail, see, for example, Baumgartner and Ferry (1991). In the literature, two endmember cases have been discussed for understanding and interpreting metasomatism: i) infiltration of a disequilibrium fluid driving mineral/rock composition changes (e.g., Korzhinskii 1968; Hofmann et al. 1974, Dipples and Gerdes, 1998; Steefel and MacQuarrie 1996); or ii) metasomatism due to changes in solubility as a consequence of pressure and temperature changes in flow direction (e.g., Phillips 


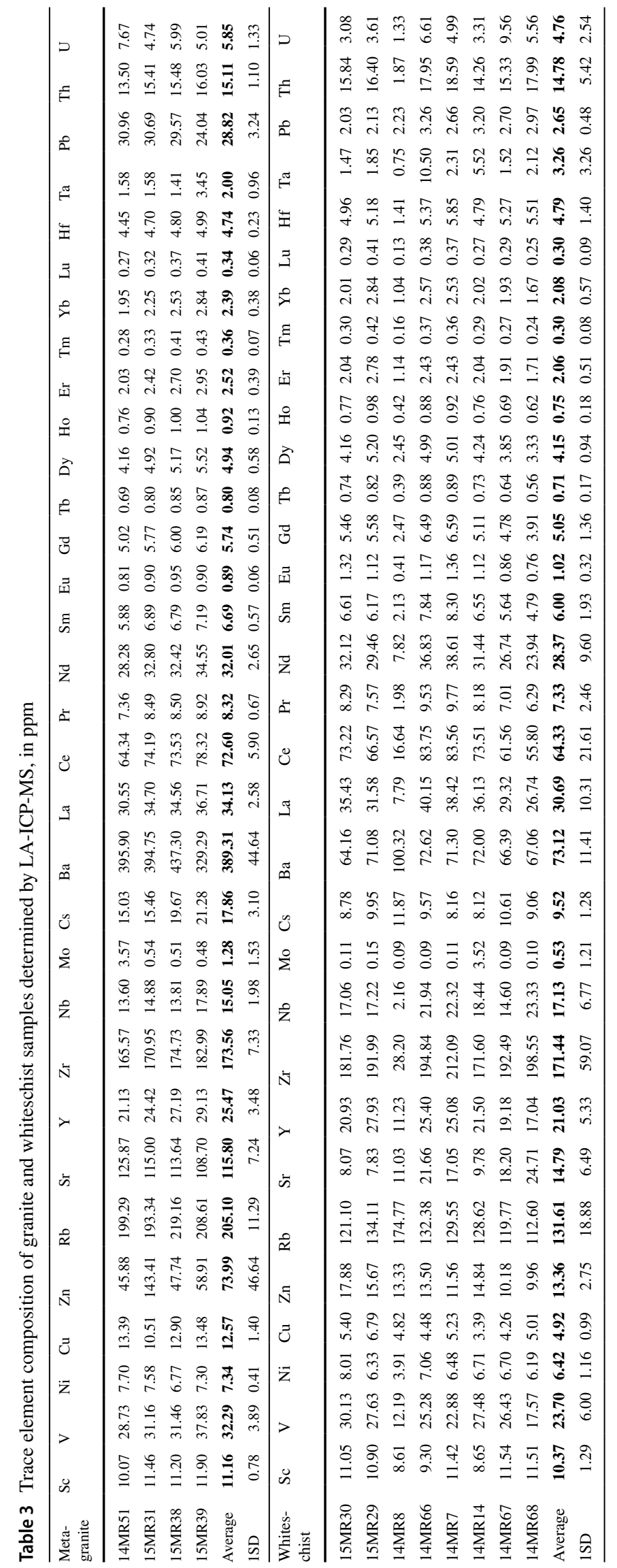


Table 4 Whole rock compositions (in wt\%) of samples along the profile starting at the Mezzalama whiteschist (WS) towards the host rock paragneisses in the NW (red line on Fig. 2d)

\begin{tabular}{|c|c|c|c|c|c|c|c|c|c|c|c|c|c|c|c|}
\hline Sample & Zone & Distance (m) & $\mathrm{SiO}_{2}$ & $\mathrm{TiO}_{2}$ & $\mathrm{Al}_{2} \mathrm{O}_{3}$ & $\mathrm{Fe}_{2} \mathrm{O}_{3}$ & $\mathrm{FeO}$ & $\mathrm{MnO}$ & $\mathrm{MgO}$ & $\mathrm{CaO}$ & $\mathrm{Na}_{2} \mathrm{O}$ & $\mathrm{K}_{2} \mathrm{O}$ & $\mathrm{P}_{2} \mathrm{O}_{5}$ & $\mathrm{H}_{2} \mathrm{O}$ & Total \\
\hline 5MR30* & Zone $\mathrm{A}_{\text {in }}$ & 0.02 & 62.38 & 0.47 & 17.13 & 2.39 & 1.62 & 0.04 & 8.24 & 0.22 & 0.15 & 3.02 & 0.18 & 3.84 & 99.68 \\
\hline 15MR29* & Zone $\mathrm{A}_{\mathrm{in}}$ & 0.04 & 63.62 & 0.52 & 16.94 & 2.30 & 1.25 & 0.03 & 7.56 & 0.06 & 0.18 & 3.36 & 0.07 & 3.71 & 99.58 \\
\hline 14MR8* & Zone $\mathrm{A}_{\text {in }}$ & 0.06 & 62.39 & 0.09 & 18.81 & 1.52 & 1.20 & 0.03 & 5.86 & 0.45 & 0.27 & 4.47 & 0.35 & 4.11 & 99.54 \\
\hline 14MR66* & Zone $\mathrm{A}_{\mathrm{in}}$ & 0.08 & 62.66 & 0.48 & 16.17 & 1.84 & 1.62 & 0.04 & 7.50 & 0.88 & 0.34 & 3.10 & 0.66 & 4.46 & 99.75 \\
\hline 14MR7* & Zone $\mathrm{A}_{\mathrm{in}}$ & 0.10 & 65.00 & 0.58 & 15.30 & 1.21 & 1.48 & 0.03 & 7.28 & 0.84 & 0.20 & 3.12 & 0.65 & 4.07 & 99.74 \\
\hline 14MR14* & Zone $\mathrm{A}_{\mathrm{in}}$ & 0.20 & 64.62 & 0.46 & 15.42 & 0.62 & 2.68 & 0.03 & 7.59 & 0.19 & 0.26 & 3.11 & 0.14 & 4.70 & 99.82 \\
\hline 14MR15* & Zone $A_{\text {out }}$ & 0.30 & 64.66 & 0.25 & 17.98 & 0.80 & 1.40 & 0.02 & 4.86 & 0.26 & 0.33 & 5.11 & 0.20 & 4.09 & 99.96 \\
\hline 14MR16B & Zone $\mathrm{A}_{\text {out }}$ & 0.60 & 67.70 & 0.40 & 15.27 & 0.94 & 1.45 & 0.02 & 5.31 & 0.33 & 0.27 & 4.20 & 0.21 & 3.75 & 99.85 \\
\hline 14MR16C & Zone $A_{\text {out }}$ & 0.62 & 59.52 & 0.68 & 17.69 & 1.25 & 2.19 & 0.04 & 8.13 & 0.38 & 0.29 & 4.39 & 0.23 & 5.12 & 99.90 \\
\hline $14 \mathrm{MR} 16 \mathrm{H}$ & Zone $\mathrm{A}_{\text {out }}$ & 0.65 & 63.55 & 0.13 & 18.94 & 0.64 & 1.32 & 0.02 & 4.42 & 0.41 & 0.35 & 5.95 & 0.30 & 3.88 & 99.91 \\
\hline 14MR17 & Zone $\mathrm{A}_{\text {out }}$ & 0.75 & 98 & 0.42 & 15.94 & 0.5 & 2.05 & 0.03 & 5.64 & 0.33 & 0. & 4.47 & 0.20 & 3.94 & 99.83 \\
\hline 4MR18* & Zone B & 0.90 & .48 & 0.53 & 15.80 & 0.78 & 2.07 & 0.04 & 5.54 & 0.37 & 2.12 & 3.56 & 0.19 & 3.29 & 99.76 \\
\hline 4MR19B & e B & 1.10 & 76 & 0.30 & 16.53 & 0.89 & 2.23 & 0.04 & 6.15 & 0.37 & 2.24 & 3.66 & 0.14 & 3.56 & 99.88 \\
\hline $19 \mathrm{H}$ & $B$ & 1 & 5 & 0.47 & 1 & 0 & 1.66 & 0.03 & 4.73 & 0.53 & 2.16 & 3.48 & .24 & 2.59 & 99.77 \\
\hline $2 \mathrm{H}^{*}$ & Zone B & 1. & 77 & 0.55 & 1 & 0 & 0.48 & 0.02 & 1.90 & 0.81 & 0.47 & 5.43 & 0.20 & 2.41 & 99.59 \\
\hline J & Z & 3 & 6 & 0 & 1 & 1 & 1 & 0 & 0.94 & 7 & 3.00 & 3.87 & 8 & 2.02 & 9.79 \\
\hline 4.2 & $z$ & 4.97 & & 0 & 1 & 1.20 & 9 & 0.08 & 8 & 6 & 2.35 & 4.53 & 8 & .19 & 99.92 \\
\hline 1 & Z & 6 & 4 & 0 & 1 & 1 & 4 & 0 & 0.89 & 8 & 0 & 4.14 & 9 & 1.49 & 99.77 \\
\hline 14 & 1 & 9 & 9 & 0 & 1 & 0 & 2.02 & 0 & 0.92 & 1.39 & 8 & 4.56 & 1 & 1.58 & 99.85 \\
\hline 14MR47 & tagranite & 15.07 & 8 & 0.41 & 14 & 0.5 & 1.58 & 0.06 & 0.80 & 1.34 & 3.15 & 4.72 & 0.20 & 1.22 & 99.98 \\
\hline 14MR48 & Metagranite & 23.77 & 68.99 & 0.48 & 15.18 & 1.32 & 1.68 & 0.07 & 0.89 & 1.58 & 3.41 & 4.77 & 0.20 & 1.24 & 99.80 \\
\hline 14MR49 & Metagranite & 32.37 & 73.16 & 0.35 & 13.42 & 0.52 & 1.59 & 0.05 & 0.75 & 1.18 & 2.94 & 4.52 & 0.16 & 1.31 & 99.95 \\
\hline 14MR50* & Metagranite & 40.77 & 69.17 & 0.48 & 15.06 & 1.16 & 1.81 & 0.07 & 0.92 & 1.53 & 3.27 & 4.83 & 0.19 & 1.23 & 99.71 \\
\hline 14MR51* & Metagranite & 47.77 & 71.99 & 0.43 & 13.77 & 1.08 & 1.59 & 0.05 & 0.75 & 1.62 & 2.81 & 4.36 & 0.19 & 1.18 & 99.81 \\
\hline 14MR52 & Metagranite & 53.02 & 70.78 & 0.47 & 14.32 & 0.93 & 1.91 & 0.05 & 0.82 & 1.69 & 2.87 & 4.46 & 0.19 & 1.40 & 99.88 \\
\hline 14MR53 & Metagranite & 58.47 & 70.35 & 0.49 & 14.48 & 1.30 & 1.74 & 0.06 & 0.87 & 1.81 & 3.11 & 4.11 & 0.20 & 1.43 & 99.95 \\
\hline 14MR54.2 & Metagranite & 60.59 & 69.91 & 0.44 & 14.93 & 1.04 & 1.72 & 0.07 & 0.79 & 1.49 & 3.34 & 4.58 & 0.22 & 1.36 & 99.86 \\
\hline 14MR55 & Transition & 64.89 & 72.44 & 0.33 & 13.69 & 0.84 & 1.63 & 0.03 & 2.90 & 0.48 & 1.37 & 3.37 & 0.19 & 2.65 & 99.92 \\
\hline 14MR56* & WS boundary & 65.89 & 66.01 & 0.18 & 16.31 & 0.83 & 1.99 & 0.03 & 5.02 & 0.33 & 0.50 & 4.34 & 0.18 & 4.03 & 99.76 \\
\hline 14MR64* & WS boundary & 66.00 & 64.31 & 0.47 & 16.25 & 0.91 & 2.67 & 0.03 & 6.37 & 0.28 & 0.41 & 3.43 & 0.21 & 4.60 & 99.95 \\
\hline
\end{tabular}

$\mathrm{Fe}_{2} \mathrm{O}_{3}$ and $\mathrm{FeO}$ were determined by calorimetric method. Samples with an asterisk were used for $\mathrm{H}_{2} \mathrm{O}$ determination by TC/EA. For others, $\mathrm{H}_{2} \mathrm{O}$ corresponds to the LOI calculated by weight difference after calcination. Data is plotted in Fig. 8a

1990; Baumgartner and Ferry 1991; Steefel and MacQuarrie 1996). Case (i) is readily understood as a fluid emanating for example from a typical ultramafic rock will be in contact with high-solubility Mg-bearing minerals and hence contain a high amount of total $\mathrm{Mg}$. In contrast, the same fluid will be highly undersaturated with potassium, since serpentinites do not contain significant amounts of K-bearing minerals. If this ultramafic rock derived fluid infiltrates a granite it may produce a $\mathrm{Mg}$ metasomatism and, at the same time, leach potassium, for example. The second case is due to the fact that pressure and temperature change the solubility of minerals, and hence, flow in a $\mathrm{P} / \mathrm{T}$ gradient results in concentration changes in the fluid, reflected by dissolution/precipitation of minerals in the rock. For example, a chloride-bearing fluid flowing down a temperature gradient-i.e., fluid is flowing towards lower temperatures-in a K-feldspar-albite-muscovite-quartz-bearing granite or pelitic rock will preferentially dissolve $\mathrm{Na}$, and precipitate $\mathrm{K}$, since the solubility of $\mathrm{Na}$ at equilibrium increases, while that of $\mathrm{K}$ decreases (e.g., Can 2002; Miron et al. 2016). A quantitative evaluation of the solubility of minerals is difficult, since the high-pressure metamorphism has changed the mineralogy of the protholith through closed system metamorphism, and hence, we propose a qualitative discussion here.

The fact that the major elements-aluminium, silica, and even potassium - were neither added nor leached from the rock (Figs. 6,7) suggests a fluid which has reached equilibrium with respect to these components in the granite, while sodium and calcium - mostly present in plagioclasewere leached and replaced by a Mg-rich silicate. A similar 
Table 5 Whole rock $\delta \mathrm{D}$ and $\delta^{18} \mathrm{O}($ in $\%$ ) values for a selection of the samples in Table 4 for the transition from the whiteschist to metagranite (red line on Fig. 2d)

\begin{tabular}{|c|c|c|c|c|c|c|}
\hline Sample & Type & $\begin{array}{l}\text { Distance from } \\
\text { WS (m) }\end{array}$ & $\delta \mathrm{D}(\% \circ)$ & $\pm 2 \mathrm{SD}$ & $\delta^{18} \mathrm{O}(\% 0)$ & $\pm 1 \mathrm{SD}$ \\
\hline 15MR30 & Zone $A_{\text {in }}$ & 0.02 & -63 & 0.91 & 8.3 & 0.04 \\
\hline $15 \mathrm{MR} 29$ & Zone $A_{\text {in }}$ & 0.04 & -59 & 1.22 & 8.5 & 0.04 \\
\hline 14MR8 & Zone $A_{\text {in }}$ & 0.06 & -58 & 0.69 & 8.7 & 0.04 \\
\hline 14MR66 & Zone $\mathrm{A}_{\text {in }}$ & 0.08 & -57 & 1.14 & 9.3 & 0.04 \\
\hline 14MR7 & Zone $\mathrm{A}_{\text {in }}$ & 0.10 & -59 & 0.04 & 8.8 & 0.04 \\
\hline 14MR14 & Zone $A_{\text {in }}$ & 0.20 & -50 & 2.02 & 8.8 & 0.30 \\
\hline $14 \mathrm{MR} 15$ & Zone $\mathrm{A}_{\text {out }}$ & 0.30 & -54 & 0.32 & 9.2 & 0.30 \\
\hline 14MR18 & Zone B & 0.90 & -56 & 1.53 & & \\
\hline $14 \mathrm{MR} 42 \mathrm{H}$ & Zone B & 1.72 & -56 & 0.27 & 10.2 & 0.12 \\
\hline 14MR44,2 & Zone $\mathrm{C}$ & 4.97 & & & 10.4 & 0.30 \\
\hline 14MR45 & Zone C & 6.67 & -66 & 0.09 & 11.4 & 0.30 \\
\hline 14MR50 & Metagranite & 40.77 & -73 & 1.14 & 11.5 & 0.30 \\
\hline 14MR51 & Metagranite & 47.77 & -75 & 1.16 & 11.5 & 0.30 \\
\hline 14MR56 & WS boundary & 65.89 & -55 & 0.62 & 8.9 & 0.30 \\
\hline 14MR64 & WS boundary & 66.00 & -51 & 0.01 & 8.3 & 0.30 \\
\hline
\end{tabular}

Table 6 Bulk carbonate $\delta^{13} \mathrm{C}$ and $\delta^{18} \mathrm{O}$ (in \%o) compositions of samples from zone $\mathrm{C}$ of the Mezzalama whiteschist transition zone

\begin{tabular}{lcc}
\hline Sample & $\begin{array}{l}\delta^{13} \mathrm{C} \text { VPDB } \\
(\% o)\end{array}$ & $\begin{array}{l}\delta^{18} \mathrm{O} \\
\text { VSMOW } \\
(\% o)\end{array}$ \\
\hline 14MR12 & -6.5 & 10.8 \\
14MR10 & -7.0 & 9.9 \\
14MR11 & -6.7 & 9.3 \\
14MR43 & -6.7 & 10.3 \\
14MR44 & -6.9 & 10.6 \\
14MR45 & -7.6 & 10.3 \\
99SL124-1 & -9.6 & 10.1 \\
99SL124-2 & -9.7 & 9.5 \\
99SL124-3 & -9.7 & 9.6 \\
99SL144-1 & -9.7 & 9.8 \\
99SL144-2 & -9.8 & 9.6 \\
\hline
\end{tabular}

Data from Pawlig and Baumgartner (2001) are from the carbonate vein of the Vera whiteschist (marked with ${ }^{\circ}$ for comparison). Uncertainty is \pm 0.11 and $0.12 \%$ (1SD) for $\delta^{13} \mathrm{C}$ and $\delta^{18} \mathrm{O}$ respectively

alteration was observed by Baumgartner and Olsen (1995) for the porphyry copper Bingham (Utah, USA) sericite-biotite alteration zone, where mostly sodium and calcium were leached, together with minor iron, yielding a potassium-rich rock. We propose a similar alteration, but occurring at a slightly lower temperature, in the chlorite field. In that case, $\mathrm{Mg}$ would have been increasing as well, since chlorite in equilibrium with the same fluid as biotite is generally more Mg-rich (e.g., Spear 1995). A fluid emanating directly from serpentinites, as proposed by other workers for the whiteschists of the internal crystalline massifs (Sharp et al. 1993;
Demény et al. 1997; Barnes et al. 2004; Ferrando et al. 2009), would have resulted in leaching of $\mathrm{K}_{2} \mathrm{O}$ and $\mathrm{SiO}_{2}$ and an enrichment of $\mathrm{Ni}$ and $\mathrm{Cr}$, which is not the case for the Monte Rosa whiteschists.

Evaporite-derived fluids, as suggested by Ferrando et al. (2009), could be a source for high Mg fluids, but they would have also high concentrations of sodium and calcium due to potential halite, dolomite, or calcite contents of the sediments. Since these elements were found to be leached from the granite protolith, such a source is unlikely.

Similarly, seawater-driven serpentinization of the mantle at the base of the continental crust during Mesozoic extension would be enriched in sodium and likely calcium from seawater in addition to magnesium. Hydration of the mantle would increase the salinity additionally, resulting in sodiumrich brines. A further argument against such a scenario is the missing of pervasive brittle structures, which would grant access to the interior part of the Monte Rosa rocks. Following Manatschal et al. (2000), we would expect fluids to be channelized along detachment faults, rather than undulating, reaction fingering type structures (Luisier et al. 2019).

Finally, seawater fluids do not bear isotopic heavy strontium signatures (seawater ${ }^{87} \mathrm{Sr} /{ }^{86} \mathrm{Sr}=0.709$; Faure, 1972). Therefore, they would result in lower radiogenic $\mathrm{Sr}$ values during alteration, not seen in the measured high ${ }^{87} \mathrm{Sr} /{ }^{86} \mathrm{Sr}$ ratios of the whiteschists (Fig. 10). Consequently, field observations and whole rock as well as radiogenic isotopes argue against fluids during the Mesozoic extensional regime. This leaves, as most probable metasomatic event, the late magmatic-hydrothermal alteration of the granite.

The whiteschist $\delta \mathrm{D}$ and $\delta^{18} \mathrm{O}$ values can be used to estimate the composition of the fluid in equilibrium with their protolith, provided that the mineralogy of the metasomatic 
Table 7 Whole rock ${ }^{87} \mathrm{Sr} /{ }^{86} \mathrm{Sr}$, $\mathrm{Rb}$ (ppm) and $\mathrm{Sr}$ (ppm) compositions and calculated ${ }^{87} \mathrm{Rb} /{ }^{86} \mathrm{Sr}$ for several whiteschist, granite gneiss and porphyritic metagranite

\begin{tabular}{|c|c|c|c|c|c|c|}
\hline Sample & $\mathrm{Rb}(\mathrm{ppm})$ & $\mathrm{Sr}(\mathrm{ppm})$ & ${ }^{87} \mathrm{Rb} /{ }^{86} \mathrm{Sr}$ & $\pm(1 \mathrm{SD})$ & ${ }^{87} \mathrm{Sr} /{ }^{86} \mathrm{Sr}$ & $\pm(1 \mathrm{SD})$ \\
\hline \multicolumn{7}{|c|}{ Porphyritic metagranites } \\
\hline 15MR51 & 207 & 121 & 4.959952 & 1.794018 & 0.733997 & 0.000002 \\
\hline 15MR31 & 204 & 110 & 5.380814 & 3.039819 & 0.732980 & 0.000002 \\
\hline $15 \mathrm{MR} 38$ & 229 & 108 & 6.115557 & 1.587514 & 0.735807 & 0.000002 \\
\hline 15MR39 & 216 & 103 & 6.060260 & 1.636704 & 0.734465 & 0.000002 \\
\hline \multicolumn{7}{|c|}{ Whiteschist, inner } \\
\hline $15 \mathrm{MR} 30$ & 124 & 6 & 61.223529 & 0.382099 & 0.794286 & 0.000009 \\
\hline 15MR29 & 138 & 6 & 69.461578 & 0.611310 & 0.800075 & 0.000015 \\
\hline 14MR8 & 182 & 9 & 58.972831 & 1.425061 & 0.800243 & 0.000007 \\
\hline 14MR66 & 137 & 19 & 21.056378 & 1.189496 & 0.763703 & 0.000003 \\
\hline 14MR7 & 136 & 15 & 27.177414 & 0.582409 & 0.760803 & 0.000004 \\
\hline 14MR14 & 129 & 8 & 48.938169 & 0.155242 & 0.790161 & 0.000011 \\
\hline 14MR67 & 124 & 16 & 22.889283 & 0.547083 & 0.765094 & 0.000005 \\
\hline 14MR68 & 118 & 22 & 15.451198 & 1.795132 & 0.755985 & 0.000003 \\
\hline \multicolumn{7}{|l|}{ Granite* } \\
\hline 98SL133 & 248 & 124 & 5.802402 & 0.122217 & 0.735778 & 0.000016 \\
\hline 99SL125 & 183 & 116 & 4.575723 & 0.096379 & 0.733153 & 0.000011 \\
\hline 99SL159 & 225 & 110 & 5.934429 & 0.124998 & 0.736145 & 0.000011 \\
\hline \multicolumn{7}{|c|}{ Granitic Gneiss* } \\
\hline 99SL115 & 226 & 15 & 43.96935 & 0.926135 & 0.79626 & 0.000062 \\
\hline 99SL118 & 200 & 84 & 6.911287 & 0.145574 & 0.741217 & 0.00003 \\
\hline 99SL119 & 177 & 20 & 25.7923 & 0.543268 & 0.782354 & 0.00003 \\
\hline 99SL127 & 289 & 20 & 42.04978 & 0.885703 & 0.766935 & 0.000018 \\
\hline 99SL128 & 174 & 69 & 7.32751 & 0.154341 & 0.751803 & 0.000773 \\
\hline 99SL153 & 188 & 55 & 9.925469 & 0.209062 & 0.744705 & 0.000014 \\
\hline \multicolumn{7}{|c|}{ Whiteschist* } \\
\hline 98SL132 & 200 & 11 & 53.15938 & 1.119706 & 0.815501 & 0.000086 \\
\hline 99SL110 & 235 & 18 & 38.11048 & 0.802728 & 0.79902 & 0.000013 \\
\hline 99SL120 & 191 & 19 & 29.3348 & 0.617884 & 0.795559 & 0.000024 \\
\hline 99SL121 & 205 & 14 & 42.80366 & 0.901582 & 0.813419 & 0.000005 \\
\hline 99SL140 & 197 & 8 & 72.05005 & 1.517604 & 0.823008 & 0.000101 \\
\hline 99SL149 & 92 & 16 & 16.75503 & 0.352914 & 0.780706 & 0.000009 \\
\hline 99SL152 & 183 & 12 & 44.54521 & 0.938264 & 0.80572 & 0.000015 \\
\hline
\end{tabular}

Data with the $*$ are from Pawlig (2001) and concern the Vera outcrop. Others are from the Mezzalama area. Nomenclature of Pawlig (2001) was kept for her samples in order to stay consistent rock is known, as well as the alteration temperature. Fluid $\delta \mathrm{D}$ and $\delta^{18} \mathrm{O}$ values were calculated based on a fluid in equilibrium with the precursor mineralogy of the whiteschist at $300-350{ }^{\circ} \mathrm{C}$. The precursor mineralogy of the whiteschist was obtained by calculating the stable mineralogy using the bulk composition of the whiteschist (sample investigated in Luisier et al. 2019). A temperature of $300{ }^{\circ} \mathrm{C}$ and $2 \mathrm{kbar}$ was assumed, corresponding to a typical estimate for the late hydrothermal system around a shallow granite intrusion (e.g., Cook et al. 1997; Bégué et al. 2019). The predicted mineral assemblage is chlorite (25\%), white mica $(25 \%)$, chloritoid (5\%), and quartz (45\%). The $\delta \mathrm{D}$ and $\delta^{18} \mathrm{O}$ values of the whiteschist samples used for fluid composition calculations are listed in Table 5 (six samples from Zone $A_{\text {in }}$ ).
Oxygen isotope fractionation coefficients (used as $\Delta_{\min -\mathrm{H} 2 \mathrm{O}}$ ) are from Zheng (1993) for chloritoid, talc, phengite, quartz, and from Cole (1985) for chlorite. Hydrogen isotope fractionation coefficients $\left(\Delta_{\min -\mathrm{H} 2 \mathrm{O}}\right)$ are from Graham et al. (1987) for chlorite and from Suzuoki and Epstein (1976) for muscovite. The mole fractions of oxygen and hydrogen are calculated using estimated modal proportions to determine the whole-rock- $\mathrm{H}_{2} \mathrm{O}$ fractionation factor. The results are shown in Fig. 12. The metasomatic fluid compositions have $\delta \mathrm{D}$ and $\delta^{18} \mathrm{O}$ values that match a mix between primary magmatic fluids and meteoric fluids. Such fluids are consistent with a late magmatic-hydrothermal fluid, derived from the mixing of late magmatic and surface-derived fluids. Through circulation within the Monte Rosa paragneiss 


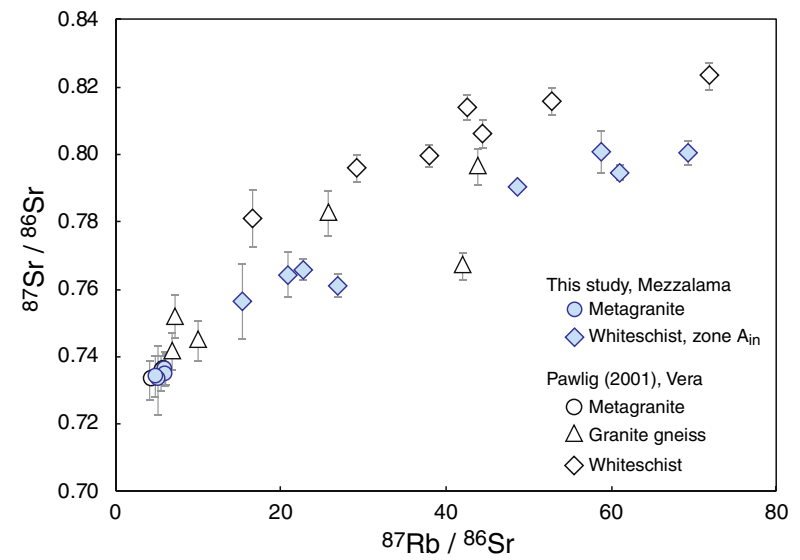

Fig. $10{ }^{87} \mathrm{Rb} /{ }^{86} \mathrm{Sr}$ and ${ }^{87} \mathrm{Sr} /{ }^{86} \mathrm{Sr}$ isotopes of whiteschists (zone $\mathrm{A}_{\text {in }}$ ) and metagranites from the Mezzalama (this study, filled symbols) and Vera (Pawlig 2001, open symbols) whiteschist outcrops. Error bars are $1 \mathrm{SD}$, which are in some cases smaller than the symbols. Note that no isochron can be defined by the data, since they plot as a nonlinear array. This suggests that the $\mathrm{Rb} / \mathrm{Sr}$ system was disturbed by the Alpine metamorphic event. See text for explanation

basement, fluids could have been enriched in radiogenic heavy strontium before reaching the granite, but highly radiogenic ${ }^{87} \mathrm{Sr} /{ }^{86} \mathrm{Sr}$ ratios could also have been obtained solely by Sr-leaching during metasomatism. Such fluids are highly reactive and susceptible to alter granites through reaction-induced fingering (e.g., Dewers and Ortoleva 1990; Omlin et al. 2017). Late magmatic-hydrothermal fluids succeed in explaining both field observations, major and trace elements, as well as stable and radiogenic isotopes. Moreover, they fit with the tectonic setting of the Monte Rosa basement during the Permian.

\section{Conclusion}

A comparison of the whole-rock chemical composition of the whiteschists and the granites confirms that the protolith of the whiteschists were produced in-situ from the enclosing granite. The strontium isotope compositions require a pre-Alpine age for the metasomatic alteration of the granite, in agreement with data presented in Marger et al. (2019). Hence, a subduction fluid origin as proposed by Sharp et al. (1993) and Ferrando et al. (2009) for other whiteschist localities can be excluded. None of the whiteschist is associated with fault structures, making proposal of fluids associated with Mesozoic, post-Hercynian orogenic collapse, and thinning of the European passive margin (Manatschal et al. 2000; Ferrando 2012; Gauthiez-Putallaz et al. 2016) unlikely. Moreover, the measured high radiogenic strontium
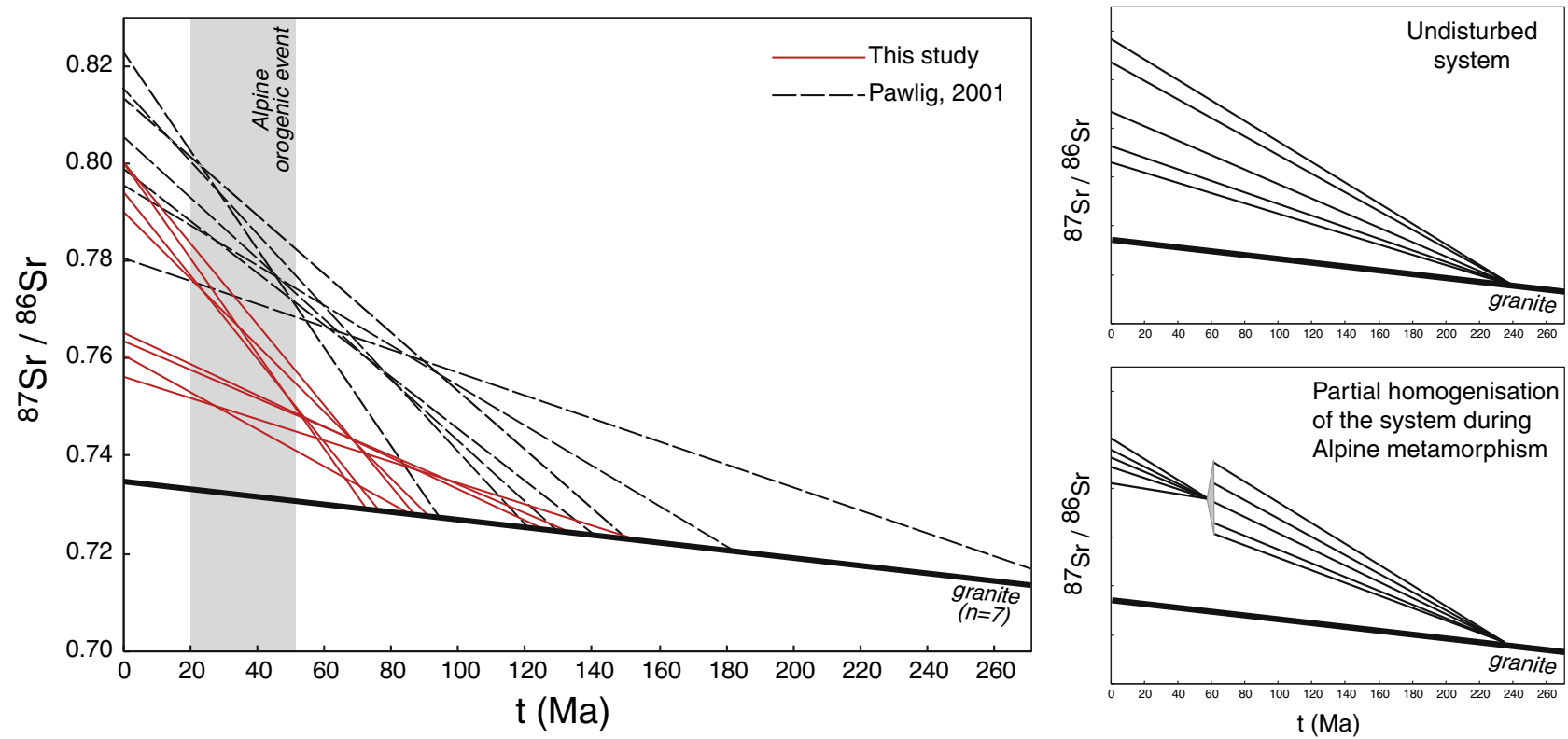

Fig. 11 Strontium evolution diagram calculated on the basis of ${ }^{87} \mathrm{Sr} /{ }^{86} \mathrm{Sr}$ data displayed in Table 7 , for the Mezzalama whiteschist (full lines) and the Vera whiteschist (dashed lines; after Pawlig 2001). The dark grey band represents the duration of the Alpine orogenic event (Hurford et al. 1991; Lapen et al. 2007; Skora et al. 2015). The intersection between the lines for each sample indicate that the $\mathrm{Rb} /$ $\mathrm{Sr}$ system was perturbed. We suggest that the $\mathrm{Sr}$ isotopic system is perturbed during the Alpine history by local, limited re-equilibration of the $\mathrm{Sr}$ isotopic system. This is likely due to dehydration reactions during the prograde reactions leading up to high-pressure metamorphism. Some additional re-equilibration might have occurred during the partial greenschist-facies overprint. On the right, two sketches illustrate an undisturbed isotopic system (above) and a partially reequilibrated system due to an isotopic perturbation (below) in order to clarify the interpretation 


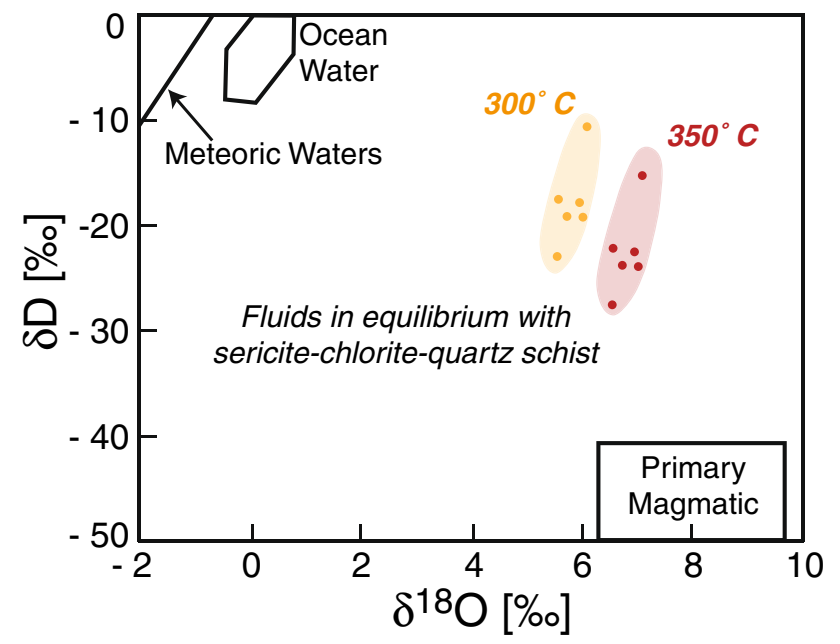

Fig. 12 Calculated $\delta \mathrm{D}$ and $\delta^{18} \mathrm{O}$ isotopic composition of fluids in equilibrium with the whiteschist protolith consisting of a sericitechlorite-quartz assemblage at 300 and $350{ }^{\circ} \mathrm{C}$. For details, see text. Fields for the primary magmatic fluids, the domain of ocean water, as well as the meteoric water line are shown for comparison. The fluids responsible for the metasomatism were likely a mix between surface waters and primary magmatic waters, typical for a late magmatic hydrothermal system

compositions of the whiteschist and the chemical signature do not support such an origin.

The above-detailed discussion rather suggests that the major-element compositions of the whiteschists reflect late magmatic-hydrothermal alteration of the granite resulting in a sericite-chlorite-quartz alteration of the granite. The fluids were undersaturated with respect to $\mathrm{Na}$ and $\mathrm{Ca}$, saturated with respect to $\mathrm{K}$ and $\mathrm{Si}$, and oversaturated with respect to $\mathrm{Mg}$. This is either related to their origin, that is their source rocks, or due to the changes in intensive variables $(\mathrm{P}, \mathrm{T})$ along the flow directions and intense fluid-rock exchange. Stable isotope compositions support fluids that have equilibrated with an igneous rock. A second, minor fluid event related to Alpine metamorphism is also suggested by the strontium isotope compositions. This leads us to propose the genetic model below.

\section{Genetic model}

The genetic model proposed involves four steps, as illustrated in Fig. 13:

(i). the intrusion of the granitic magma in the upper crust during the Permian (Pawlig 2001) with an associated large-scale thermal perturbation in the country rocks. A contact aureole was developed in the country rocks around the granite pluton (Fig. 13a).

(ii). The thermal perturbation sets up a convection (e.g., Hanson 1995; Cook et al. 1997; Gerdes et al. 1998) leading to infiltration of surface-derived fluids. Fluids reaching the granite is focussed along the granite-paragneiss contact, and locally penetrated into the granite by reaction-induced fingering. Due to the large chemical disequilibrium between the granite and the fluid, pervasive alteration of the granite is induced along tube-like structures and/or in contact zones facilitating fluid access (Fig. 13b). At this point, the stable isotope composition is reset within the rocks, reflecting a typical hydrothermal mineralogy and composition (e.g., Baumgartner and Valley 2001). The rock produced is a phyllitic or argillitic alteration containing sericite, chlorite, quartz, or smectite-illite and kaolinite, depending on the prevailing temperature during alteration. In this kind of alteration zone, all plagioclase is dissolved, and K-feldspar altered to muscovite/ illite, and biotite is altered to chlorite by these slightly acidic hydrothermal solutions (e.g., Parry et al. 2002). The presence of sulphides described by Pawlig and Baumgartner (2001) further supports this interpretation. Strontium was, along with calcium, depleted due to plagioclase breakdown, while rubidium follows potassium into the muscovite/illite. Potentially, some radiogenic ${ }^{87} \mathrm{Sr}$ could have also been leached from the surrounding pre-Hercynian schists, though this cannot be demonstrated.

During the following ca. 200 Ma years, the system is left undisturbed, accumulating radiogenic ${ }^{87} \mathrm{Sr}$ and thus increasing the ${ }^{87} \mathrm{Sr} /{ }^{86} \mathrm{Sr}$ ratios. How much radiogenic ${ }^{87} \mathrm{Sr}$ is produced will depend on the local $\mathrm{Rb}$ concentration. The overall chemical composition of the whiteschists including their bulk stable isotope compositions is not changed or perturbed during this period.

(iii). Once the Monte Rosa basement was included into the Alpine orogenic wedge, prograde metamorphism lead to the Alpine high-pressure metamorphic assemblage of chloritoid-talc-phengite-quartz and the granites received a variable metamorphic overprint (Fig. 13c). During prograde metamorphism, the crystallisation of the whiteschist produced $\mathrm{H}_{2} \mathrm{O}$, leading to local, partial homogenisation of the $\mathrm{Rb} /$ $\mathrm{Sr}$ system. The small amounts of $\mathrm{H}_{2} \mathrm{O}$ lost during prograde metamorphism did not significantly change the chemistry or the stable isotope compositions. The partial homogenisation of the $\mathrm{Rb} / \mathrm{Sr}$ system disturbed any potential isochrones, making an exact age determination impossible.

(iv). During the exhumation and backfolding of the nappe, a foliation developed, associated with retrogression of the peak Alpine paragenesis under greenschist-facies conditions, which affected the entire area (Fig. 13d). Small amounts of fluid infiltration 
A

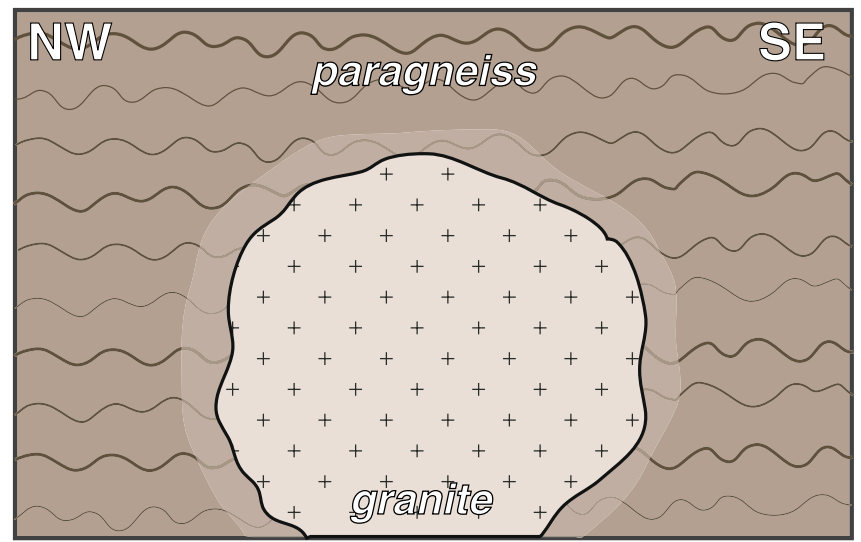

C High pressure metamorphism: $42 \mathrm{Ma}$

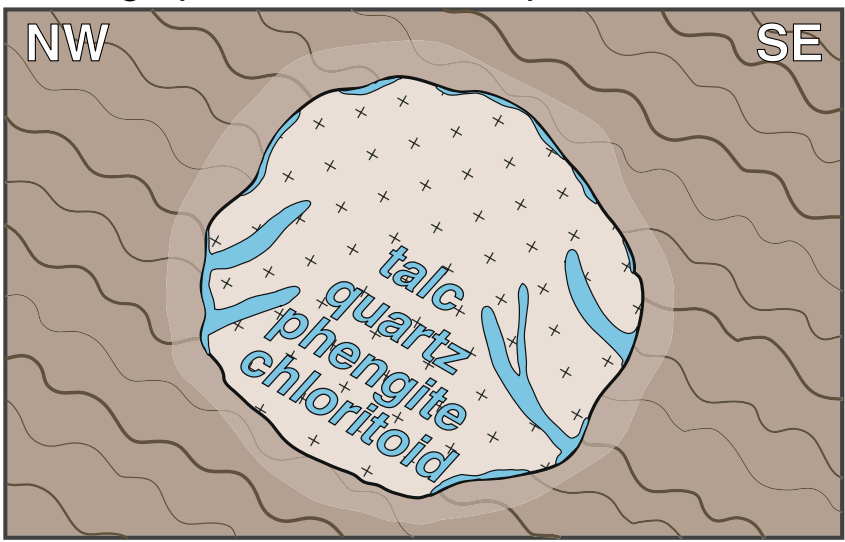

Fig. 13 Model illustrating the genesis and chronological evolution of the Monte Rosa whiteschists. Sketches are not to scale. a Intrusion of a granitoid body during the Permian (Pawlig and Baumgartner 2001) into the upper crust. This leads to the crystallisation of andalusite (Vaughan-Hammon et al., in review) in the contact aureole. b The thermal perturbation drives a hydrothermal convective circulation system. The fluid circulation pattern is illustrated by arrows. Fluids either penetrate into the granite through focused paths by reaction fingering, leading to channels or tube-like structures, or they follow the contact between granite and paragneiss. We propose that the original alteration assemblage was a chlorite, sericite and quartz rock.

\section{B Late magmatic hydrothermal alteration}

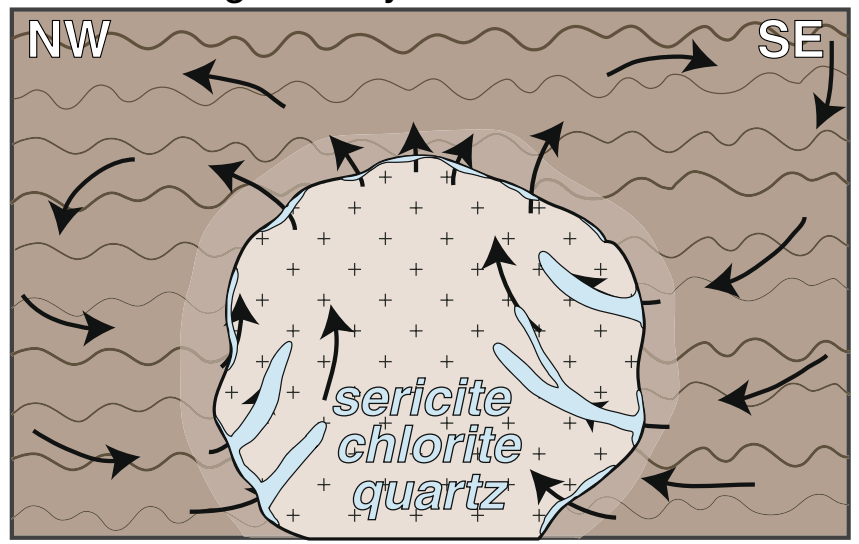

D

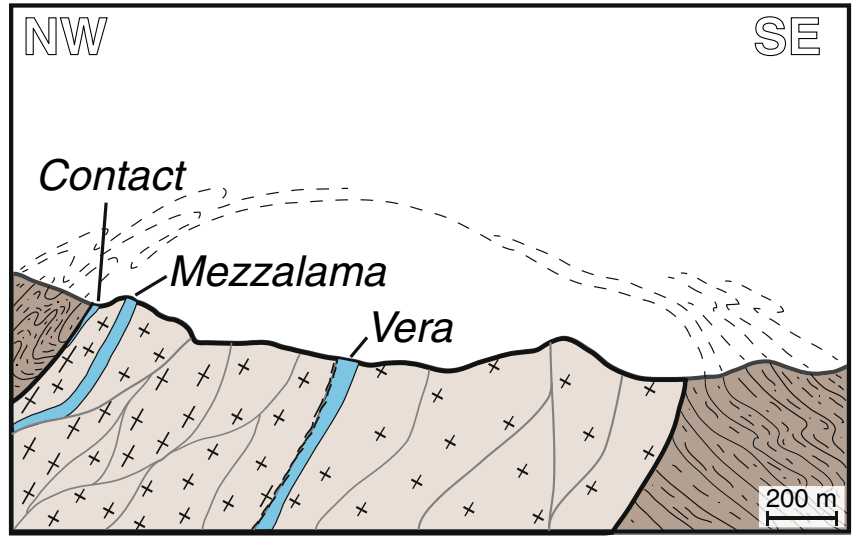

c Closed-system Alpine high-pressure metamorphism, during which fluids were expelled, produce the peak paragenesis of the whiteschists, consisting of chloritoid, phengite, talc and quartz. During that stage, the granite becomes a metagranite. $\mathbf{d}$ The whiteschist area, and much of the granite, are only slightly affected by the strong foliation overprinting the Monte Rosa nappe during exhumation and backfolding. This lead locally to a greenschist-facies partial retrogression. The form of the crosses illustrates the deformation intensity gradient in the area, decreasing from NW to SE. The cross-section is modified after Darbellay (2005)

explained. A proposed overpressure-either due to fluid overpressure or tectonic stress - as explained in detail in Luisier et al. (2019) may account for such pressure differences.

This genetic model accounts for both field observations and geochemical data of all whiteschist outcrops from the Monte Rosa nappe. As has been pointed out by many workers, whiteschist bodies are common in granitic bodies in the Western Alps (see Ferrando 2012 for a review). While the above discussion and data clearly show that no individual observation-neither field nor geochemistry—permits to uniquely demonstrate the origin of a whiteschist, it is, nevertheless, tempting to speculate that quite a few, if 
not the majority of granite-hosted whiteschists might have a similar hydrothermal origin.

\begin{abstract}
Acknowledgements This study was supported by the Swiss National Foundation grants n ${ }^{\circ} 26084159$ and 206021_163991. Cindy Luisier acknowledges the help of Massimo Chiaradia for the strontium isotope analyses and Eric May for technical support during the laser fluorination oxygen isotope analyses. We would like to thank Joshua VaughanHammon, Stefan Schmalholz, C. Chopin and F. Guillot for inspiring discussions. This study benefited from data obtained as part of the master theses of Bastien Darbellay and Mathias Dessimoz. We thank two anonymous reviewers for critical and constructive comments.
\end{abstract}

Funding Open access funding provided by University of Lausanne.

Data availability The data used in this study are available from the corresponding author upon request.

\section{Compliance with ethical standards}

Competing interest The authors declare no competing interests.

Open Access This article is licensed under a Creative Commons Attribution 4.0 International License, which permits use, sharing, adaptation, distribution and reproduction in any medium or format, as long as you give appropriate credit to the original author(s) and the source, provide a link to the Creative Commons licence, and indicate if changes were made. The images or other third party material in this article are included in the article's Creative Commons licence, unless indicated otherwise in a credit line to the material. If material is not included in the article's Creative Commons licence and your intended use is not permitted by statutory regulation or exceeds the permitted use, you will need to obtain permission directly from the copyright holder. To view a copy of this licence, visit http://creativecommons.org/licenses/by/4.0/.

\section{References}

Ague JJ (2003) Fluid infiltration and transport of major, minor, and trace elements during regional metamorphism of carbonate rocks, Wepawaug Schist, Connecticut, USA. Am J Sci 303:753-816

Ague JJ, van Haren JLM (1996) Assessing metasomatic mass and volume changes using the bootstrap, with application to deep crustal hydrothermal alteration of marble. Econ Geol 91:1169-1182

Barnes JD, Selverstone J, Sharp ZD (2004) Interactions between serpentinite devolatilization, metasomatism and strike-slip strain localization during deep-crustal shearing in the Eastern Alps. J Metamorp Geol 22:283-300

Bauer KK, Vennemann TW (2014) Analytical methods for the measurement of hydrogen isotope composition and water content in clay minerals by TC/EA. Chem Geol 363:229-240

Baumgartner LP, Olsen SN (1995) A least-squares approach to mass transport calculations using the isocon method. Econ Geol 90:1261-1270

Baumgartner LP, Valley JW (2001) Stable isotope transport and contact metamorphic fluid flow. Rev Mineral Geochem 43:415-467

Bearth P (1952) Geologie und petrographie des monte rosa. Beitr. Geol. Karte Schweiz NF 96, p 94

Bégué F, Baumgartner LP, Bouvier A-S, Robyr M (2019) Reactive fluid infiltration along fractures: textural observations coupled to in-situ isotopic analyses. Earth Planet Sci Lett 519:264-273
Béguelin P, Chiaradia M, Beate B, Spikings R (2015) The Yanaurcu volcano (Western Cordillera, Ecuador): a field, petrographic, geochemical, isotopic and geochronological study. Lithos 218-219:37-53

Can I (2002) A new improved $\mathrm{Na} / \mathrm{K}$ geothermometer by artificial neural networks. Geothermics 31:751-760

Chen Y-X, Lu W, He Y, Schertl H-P, Zheng Y-F, Xiong J-W, Zhou $\mathrm{K}$ (2019) Tracking Fe mobility and Fe speciation in subduction zone fluids at the slab-mantle interface in a subduction channel: a tale of whiteschist from the Western Alps. Geochim Cosmochim Acta 267:1-16

Chopin C (1981) Talc-phengite: a widespread assemblage in highgrade pelitic blueschists of the Western Alps. J Petrol 22:628-650

Chopin C (1984) Coesite and pure pyrope in high-grade blueschists of the Western Alps: a first record and some consequences. Contrib Miner Petrol 86:107-118

Chopin C, Monié P (1984) A unique magnesiochloritoid-bearing, high-pressure assemblage from the Monte Rosa, Western Alps: petrologic and 40Ar-39Ar radiometric study. Contrib Miner Petrol $87: 388-398$

Chopin C, Schreyer W (1983) Magnesiocarpholite and magnesiochloritoid: two index minerals of pelitic blueschists and theri preliminary phase relations in the model system. Am J Sci 283-A:72-96

Chopin C, Henry C, Michard A (1991) Geology and petrology of the coesite-bearing terrain, Dora Maira massif, Western Alps. Eur J Mineral 3:263-292

Cole (1985) A preliminary evaluation of oxygen isotopic exchange between chlorite water. Geol Soc Am Abstr Programs 17:550

Compagnoni R, Hirajima T (2001) Superzoned garnets in the coesitebearing Brossasco-Isasca Unit, Dora-Maira massif, Western Alps, and the origin of the whiteschists. Lithos 57:219-236

Cook SJ, Bowman JR, Forster CB (1997) Contact metamorphism surrounding the Alta stock: finite element model simulation of heatand ${ }^{18} \mathrm{O} /{ }^{16} \mathrm{O}$ mass-transport during prograde metamorphism. Am J Sci 297:1-55

Dal Piaz GV (1971) Nuovi ritrovamenti di cianite alpina nel cristallino antico del Monte Rosa. Rend Soc It Min Pet 27:437-477

Dal Piaz GV (2001) Geology of the Monte Rosa massif: historical review and personal comments. Schweiz Mineral Petrogr Mitt 81:275-303

Dal Piaz GV, Lombardo B (1986) Early alpine eclogite metamorphism in the Penninic Monte Rosa-Gran Paradiso basement nappes of the northwestern Alps. Geol Soc Am Mem 164:249-266

Darbellay B (2005) Histoire polymétamorphique de la nappe du Mont Rose et contraintes isotopiques. Master Thesis, University of Lausanne, Switzerland

Demény A, Sharp ZD, Pfeifer H-R (1997) Mg-metasomatism and formation conditions of $\mathrm{Mg}$-chlorite-muscovite-quartzphyllites (leucophyllites) of the Eastern Alps (W. Hungary) and their relations to Alpine whiteschists. Contrib Miner Petrol 128:247-260

Dewers T, Ortoleva P (1990) A coupled reaction/transport/mechanical model for intergranular pressure solution, stylolites, and differential compaction and cementation in clean sandstones. Geochim Cosmochim Acta 54:1609-1625

Dipple GM, Wintsch RP, Andrews MS (1990) Identification of the scales of differential element mobility in a ductile fault zone. $\mathrm{J}$ Metamorph Geol 8:645-661

Dipple GM, Gerdes ML, Lentz DR (1998) Reaction-infiltration feedback and hydrodynamics at the skarn front. Mineralized intrusionrelated skarn systems: Mineralogical Association of Canada Short Course 26:71-97

Faure G (1998) Principles and applications of geochemistry. PrenticeHall Inc., New Jersey

Faure G, Powell JL (1972) The geochemistry of rubidium and strontium. In: Faure G, Powell JL (eds) Strontium isotope geology. Springer, Berlin, pp 1-8 
Ferrando S (2012) Mg-metasomatism of metagranitoids from the Alps: genesis and possible tectonic scenarios. Terra Nova 24:423-436

Ferrando, J., Scambelluri, M., Dal Piaz, G.V., and Piccardo, G.B. (2002) The mafic boudins of the southern Furgg-Zone, Monte Rosa nappe, NW-Italy: from tholeiitic continental basalts to Alpine eclogites and retrogressed products. 81 Riunione Estiva Soc. Geol. It., Torino (abstract)

Ferrando S, Frezzotti ML, Petrelli M, Compagnoni R (2009) Metasomatism of continental crust during subduction: the UHP whiteschists from the Southern Dora-Maira Massif (Italian Western Alps). J Metamorph Geol 27:739-756

Franz L, Romer RL, de Capitani C (2013) Protoliths and phase petrology of whiteschists. Contrib Miner Petrol 166:255-274

Gauthiez-Putallaz L, Rubatto D, Hermann J (2016) Dating prograde fluid pulses during subduction by in situ $\mathrm{U}-\mathrm{Pb}$ and oxygen isotope analysis. Contrib Miner Petrol 171:1-20

Gebauer D, Schertl H-P, Brix M, Schreyer W (1997) 35 Ma old ultrahigh-pressure metamorphism and evidence for very rapid exhumation in the Dora Maira Massif, Western Alps. Lithos 41:5-24

Gerdes ML, Baumgartner LP, Person M (1998) Convective fluid flow through heterogeneous country rocks during contact metamorphism. J Geophys Res 103:23983-24003

Graham CM, Viglino JA, Harmon RS (1987) Experimental study of hydrogen-isotope exchange between aluminous chlorite and water and of hydrogen diffusion in chlorite. Am Miner 72:566-579

Grant JA (1986) The isocon diagram; a simple solution to Gresens' equation for metasomatic alteration. Econ Geol 81:1976-1982

Gresens RL (1967) Composition-volume relationships of metasomatism. Chem Geol 2:47-65

Hanson RB (1995) The hydrodynamics of contact metamorphism. GSA Bull 107:595-611

Harris C, Faure K, Diamond RE, Scheepers R (1997) Oxygen and hydrogen isotope geochemistry of S- and I-type granitoids: the Cape Granite suite, South Africa. Chem Geol 143:95-114

Hoefs J (1987) Stable isotope geochemistry, 3rd edn. Springer, Berlin, p 241

Hurford AJ, Hunziker JC, Stöckhert B (1991) Constraints on the late thermotectonic evolution of the Western Alps: evidence for episodic rapid uplift. Tectonics 10:758-769

Korzhinskii DS (1968) The theory of metasomatic zoning. Miner Deposita 3:222-231

Lacroix B, Vennemann T (2015) Empirical calibration of the oxygen isotope fractionation between quartz and Fe-Mg chlorite. Geochim Cosmochim Acta 149:21-31

Lapen TJ, Johnson CM, Baumgartner LP, Piaz GVD, Skora S, Beard BL (2007) Coupling of oceanic and continental crust during Eocene eclogite-facies metamorphism: evidence from the Monte Rosa nappe, western Alps. Contrib Miner Petrol 153:139-157

Le Bayon R, de Capitani C, Frey M (2006) Modelling phase-assemblage diagrams for magnesian metapelites in the system $\mathrm{K} 2 \mathrm{O}$ $\mathrm{FeO}-\mathrm{MgO}-\mathrm{A} 12 \mathrm{O} 3-\mathrm{SiO} 2-\mathrm{H} 2 \mathrm{O}$ : geodynamic consequences for the Monte Rosa nappe, Western Alps. Contrib Miner Petrol $151: 395-412$

Luisier C, Baumgartner L, Schmalholz SM, Siron G, Vennemann T (2019) Metamorphic pressure variation in a coherent Alpine nappe challenges lithostatic pressure paradigm. Nat Commun 10:1-11

Manatschal G, Marquer D, Früh-Green GL (2000) Channelized fluid flow and mass transfer along a rift-related detachment fault (Eastern Alps, southeast Switzerland). Geol Soc Am Bull 112:21-33

Marger K, Luisier C, Baumgartner LP, Putlitz B, Dutrow BL, Bouvier A-S, Dini A (2019) Origin of Monte Rosa whiteschist from in-situ tourmaline and quartz oxygen isotope analysis by SIMS using new tourmaline reference materials. Am Miner 104:1503-1520

Miron GD, Wagner T, Kulik DA, Heinrich CA (2016) Internally consistent thermodynamic data for aqueous species in the system Na-K-Al-Si-O-H-Cl. Geochim Cosmochim Acta 187:41-78
Mukherjee PK, Gupta PK (2008) Arbitrary scaling in ISOCON method of geochemical mass balance: an evaluation of the graphical approach. Geochem J 42:247-253

Omlin S, Malvoisin B, Podladchikov YY (2017) Pore fluid extraction by reactive solitary waves in 3-D. Geophys Res Lett 44:9267-9275

Parry WT, Jasumback M, Wilson PN (2002) Clay mineralogy of phyllic and intermediate argillic alteration at Bingham, Utah. Econ Geol 97:221-239

Pawlig, S. (2001) Geological Evolution of the Monte Rosa: Constraints from Geochronology and Geochemistry of a Talc-Kyanite-Chloritoid Shear Zone within the Monte Rosa Granite (Monte Rosa Nappe, Italian Western Alps). Dissertation, University of Mainz, Germany

Pawlig S, Baumgartner LP (2001) Geochemistry of a talc-kyanitechloritoid shear zone within the Monte Rosa granite, Val d'Ayas, Italy. Schweiz Min Petrogr Mitt 81:329-346

Phillips OM (1990) Flow-controlled reactions in rock fabric. J Fluid Mech 212:263-278

Schertl H-P, Schreyer W, Chopin C (1991) The pyrope-coesite rocks and their country rocks at Parigi, Dora Maira Massif, Western Alps: detailed petrography, mineral chemistry and PT-path. Contrib Miner Petrol 108:1-21

Schreyer W (1973) Whiteschist: a high-pressure rock and its geologic significance. J Geol 81:735-739

Schreyer PDW (1974) Whiteschist, a new type of metamorphic rock formed at high pressures. Geol Rundsch 63:597-609

Schreyer W (1977) Whiteschists: their compositions and pressure-temperature regimes based on experimental, field, and petrographic evidence. Tectonophysics 43:127-144

Schreyer W, Seifert F (1969) Compatibility relations of the aluminum silicates in the systems $\mathrm{MgO}-\mathrm{Al}_{2} \mathrm{O}_{3}-\mathrm{SiO}_{2}-\mathrm{H}_{2} \mathrm{O}$ and $\mathrm{K}_{2} \mathrm{O}-\mathrm{MgO}-\mathrm{Al}_{2} \mathrm{O}_{3}-\mathrm{SiO}_{2}-\mathrm{H}_{2} \mathrm{O}$ at high pressures. Am J Sci 267:371-388

Sharp ZD, Essene EJ, Hunziker JC (1993) Stable isotope geochemistry and phase equilibria of coesite-bearing whiteschists, Dora Maira Massif, western Alps. Contrib Miner Petrol 114:1-12

Skora S, Mahlen NJ, Johnson CM, Baumgartner LP, Lapen TJ, Beard BL, Szilvagyi ET (2015) Evidence for protracted prograde metamorphism followed by rapid exhumation of the Zermatt-Saas Fee ophiolite. J Metamorph Geol 33:711-734

Spear FS (1995) Metamorphic phase equilibria and pressure-temperature-time paths, Mineralogical Society of America, p. 799

Spötl C, Vennemann TW (2003) Continuous-flow isotope ratio mass spectrometric analysis of carbonate minerals. Rapid Commun Mass Spectrom 17:1004-1006

Steck A, Masson H, Robyr M (2015) Tectonics of the Monte Rosa and surrounding nappes (Switzerland and Italy): tertiary phases of subduction, thrusting and folding in the Pennine Alps. Swiss J Geosci 108:3-34

Steefel CI, MacQuarrie KT (1996) Approaches to modeling of reactive transport in porous media. Rev Mineral Geochem 34:85-129

Suzuoki T, Epstein S (1976) Hydrogen isotope fractionation between $\mathrm{OH}$-bearing minerals and water. Geochim Cosmochim Acta 40:1229-1240

Trümpy, R. (1980) Geology of Switzerland: a guide book. Part A: an outline of the Geology of Switzerland., p. 104, Wepf, Basel, New York: Schweiz. Geol. Kommission, Basel

Valley JW (1986) Stable isotope geochemistry of metamorphic rocks. Rev Mineral 16:445-489

Zheng Y-F (1993) Calculation of oxygen isotope fractionation in hydroxyl-bearing silicates. Earth Planet Sci Lett 120:247-263

Publisher's Note Springer Nature remains neutral with regard to jurisdictional claims in published maps and institutional affiliations. 